\title{
An Analysis of leadership behaviors and leadership styles of rector candidates on the context of the rectorship election at university \\ Üniversitede rektör adaylarının liderlik davranışlarının ve liderlik stillerinin rektörlük seçimleri bağlamında incelenmesi
}

\author{
Aydın Çivilidağ
}

\section{Özet}

$\mathrm{Bu}$ araştırmanın iki amacı vardır; birincisi üniversite rektör adaylarının (katılımcılar) liderlik davranıșlarını ve ikincisi lidelik stillerini belirlemektir. İlk amaçla ilgili olarak nitel analizin durum deseni doğrultusunda çalışma yapılmıştır. Akdeniz bölgesindeki bir devlet üniversitesinde yapılan rektörlük seçimlerinde 7 rektör adayının Nisan - Temmuz 2016 tarihleri arasında öğretim üyelerine gönderdikleri 298 e-posta içerik analizine tabi tutularak incelenmiştir. Rektör adaylarının rektörlük seçim sürecinde kendilerine oy veren öğretim üyelerine (takipçilerine) gönderdikleri epostalardaki mesajlarda kullandıkları ifadeleri doküman analizine tabi tutulmuştur. Araștırmanın ikinci amaciyla ilgili olarak nitel analizin yakınsayan parallel deseni doğrultusunda çalışma yapilmıştır. Bunun için rektör adaylarının liderlik stillerini objektif olarak belirlemek amacıyla bağımsız ve gönüllü dört sosyal bilimci akademisyene on liderlik stilini tanımlayan kapalı uçlu anketler verilmiştir. Yanıtlayıcı sosyal bilimcilerin rektör adaylarıyla ilgili gözlem ve değerlendirmeleri doğrultusunda liderlik stilleri belirlenmeye çalışlmıştır. Araştırmanın ilk kısmında rektör adaylarryla ilgili olarak A-G arasinda alfabetik kodlama yapılmıştır. Araştırmada amaçlı örnekleme yöntemlerinden kolayda örnekleme tekniği kullanılmıştır. Araştırmanın geçerliliğini artırmak için betimsel analize de yer verilmiştir. Elde edilen sonuçlara göre; Rektör adaylarının

\footnotetext{
${ }^{1}$ Yrd. Doç. Dr., Akdeniz Üniversitesi, Edebiyat Fakültesi, Psikoloji Bölümü, Endüstri/Örgüt Psikolojisi Ana Bilim Dalı, aydin-civilidag@hotmail.com
} 

bağlamında incelenmesi. Journal of Human Sciences, 15(1), 77-97. doi:10.14687/jhs.v15i1.4662

collected three themes. First theme is that rector candidates' discourses to influence the followers. This theme is including four sub-themes. These are discourses of related management, discourses of related scientific studies, discourses of related educational and teaching and discourses of related scholars' working conditions and their rights subthemes. A, C and $G$ rector candidates made the most discourses $85.71 \%$ about discourses of related management sub-theme than the others. Rector candidate B made more discourses $62.50 \%$ about discourses of related scientific research subtheme than the others. Rector candidate $G$ made more discourses 100\% about related educational and teaching sub-theme than the others and B rector candidate made more discourses $83.33 \%$ about related scholars' working conditions and their rights than the others. Second theme is with respect to discourses of project- based; $G$ rector candidate made the most discourses $40 \%$ than the others. Third theme is disclosure that introduces themselves to the followers. Rector candidate F made the most discourses of introduce yourself $60 \%$ than the others. Leadership styles of rector candidates in the direction of their sending e-mails to follower when it was analysed that leadership styles of all candidates had business-oriented leadership, second $42.85 \%$ democratic leadership and it follows at the same rate relationshiporiented leadership. As a result of the social scientists that were observed and determined about leadership styles of rector candidates by four social scientists; it was found leadership style of relationship-oriented was come forward this finding follows in order of leadership styles of business-oriented and leadership style of democratic. Also, it was determined leadership style for each of rector candidates in study.

Keywords: University, rector, leadership behaviour, leadership style, business psychology, organizational psychology.

(Extended English summary is at the end of this document)

\section{Giriş}

Tüm toplumlarda ve toplumun alt gruplarında ekonomik, politik, kültür ve sosyal koşullar ne olursa olsun liderlik olgusu, geçmişten bugüne insanlar etkileşim içinde olduğu sürece vardır. Bununla birlikte liderlik yalnızca insana ait bir nitelik de değildir, pek çok hayvan türünde, düşük düzeyli omurgalılardan (örneğin; tavuk), yüksek düzeyli omurgalılara kadar (örneğin; goriller ve balinalara) liderlik ilkel biçimiyle bulunmaktadır. Özellikle hayvanın kendi doğal ortamında yapılan gözlem ve deneyim yoluyla liderliğin hiyerarşisi ve emir sırasının varlığı belirlenebilir. Liderlik, çok takipçilerine yönelik söylemleri üç temada toplanmıştır. Bunlardan ilki, Rektör adaylarının takipçilerini etkileme söylemleri (Yönetimle ilişkili söylemler, Bilimsel Çalışmalara İlişkin Söylemler, Eğitim ve Öğretime İlişkin Söylemler ve Akademisyenlerin Çalışma Koşullarına ve Haklarına İlişkin Söylemler Alt Teması). Yönetimle ilişkili söylemler alt temasında; A, C ve $G$ rektör adayları \%85.71 ile en fazla söylemde bulunmuştur. Bilimsel Çalısmalara İlişkin söylemler alt temasinda B rektör adayı \%62.50 ile en fazla söylemde bulunmuştur. Eğitim ve Öğretime İlişkin Söylemler alt temasında G rektör aday1 \%100 ile en fazla söylemde bulunmuştur. Akademisyenlerin Çalışma Koşullarına ve Haklarına İlişkin Söylemler alt temasında B rektör aday1 \%83.33 ile en fazla söylemde bulunmuş̧tur. İkincisi Proje temelli söylemler temasıyla ilgili olarak, G rektör adayı \%40 ile en fazla proje söyleminde bulunan katılımcı olmuştur. Üçüncü tema Kendilerini tanıtma söylemi temasında ise; F rektör aday $\% 60$ ile en fazla kendini tanitma söyleminde bulunmuştur. Rektör adaylarının takipçilerine gönderdikleri e-posta doğrultusunda liderlik stilleri incelendiğinde, tüm adaylarda iş yönelimli liderlik stilinin öne çıkttğı, bunu $\% 42.85$ ile demokratik liderlik ve ilisski yönelimli liderliğin aynı oranda izlediği belirlenmiştir. Dört sosyal bilimcinin liderlik stiliyle ilgili rektör adaylarını değerlendirmeleri sonucunda ise, ilişki yönelimli liderlik stilinin adaylarda öne çıttı̆̆, bunu iş yönelimli ve demokratik liderliğin izlediği bulunmuştur.

Anahtar Kelimeler: Üniversite; rektör; liderlik davranışı; liderlik stili; çalışma psikolojisi; örgüt psikolojisi. 
Çivilidağ, A. (2018). Üniversitede rektör adaylarının liderlik davranışlarının ve liderlik stillerinin rektörlük seçimleri bağlamında incelenmesi. Journal of Human Sciences, 15(1), 77-97. doi:10.14687/jhs.v15i1.4662

eski bir kavram olduğu halde bilim insanları ve araştırmacılar sürekli bu karmaşık terimi açıklamaya çalışmışlardır. Özellikle 1960’lı yıllarda liderlik, görev ve insanları yönlendiren davranışların bir kaçının birleşimi olarak düşünülmüştür. Liderliğin öncü tanımlarında bir grup süreci ve grup davranışlarına odaklanılarak, kişiliğin etkisi olarak tanımlanmıştır. Sonrasındaki tanımlamalarda liderlik; ilişkileri etkileme, güç farklılıkları, ikna, hedef başarmayı etkileme, rol farklılaşması, pekiştirme, planlama gibi farklı terimleri de kapsamıştır (Trottier, Wart ve Wang, 2008: 320).

Bir lider, grubun izlemesi gereken rotayı belirler ya da rota üzerinde etkide bulunur. Lider, belirlenen hedeflerin başarılmasında grubun önemli bir faktörüdür. İş yaşamında bu hedefler genellikle bir ürünün üretilmesi ya da bir hizmetin yerine getirilmesiyle ilgili çabadır. Politik veya sosyal örgütlerde ise lider, insanların birlikte grup hedeflerine ulaşmasında farkındalık oluşturmaya yardım eder. Grup süreci içinde liderler formal ya da informal olabilirler. Formal bir lider, grubunu büyük ölçüde sahip olduğu statü (başkan veya kral) ile etkiler. Lider, takipçileri üzerindeki otoritesiyle takipçilerini etkileyebilir, ödül ve cezaları bu şekilde verebilir. Çoğu durumda bir lider takipçileri ona inandıkları için oldukça etkilidir (Morgan, 1974: 317-318).

Liderliğin çok sayıda tanımı ve sınıflaması bulunmaktadır. En sade ifadesiyle liderlik; bir kişinin bir grup bireyi ortak bir hedefi başarması amaciyla etkilemesi sürecidir. 1920 ile 1990 yılları arasında alanyazında yayınlanan çalışmalarda 221 liderlik tanımı olduğu belirlenmiştir. Bu tanımlarda benzerlik taşıyan anlam, bir kişinin diğer kişilere bir şeyler yapturmasıdır. (Mohamed, 2016: 50). Liderlik, belirlenen hedeflere yönelik bireyleri ya da grupları davranışsal olarak etkileme sürecidir ve etkili liderlik, bu hedeflere ne kadar iyi bir şekilde ulaşıldığı yönünde tanımlanmaktadır (Barrow, 1977:232). Kotter (1999) liderliği, bir grubu belirli bir yönde hareket ettirmedeki rehberlik süreci olarak ifade ederken, etkili liderliği, grubun uzun dönemli amaçlarını içeren eylemler ortaya koyma şeklinde açıklamıştır. Etzioni (1965) liderliği, kişisel niteliklere dayalı, büyük ölçüde kesin bağllılıla ilgili eylemleri amaçlayan özel türde güç becerisi olarak tanımlamıştır. Bu anlamda liderlik kavramı; bireyleri ikna etmeyi, yeni fikirler öne sürmeyi, yüksek kapasiteli karar vermeyi içermektedir (Mihai, Schiopoiu ve Mihai, 2017:5).

Liderlik ve yöneticilik kavramları alanyazında sıklıkla eş anlamlı kullanılmıştır, liderlik ve yöneticilik kavramları arasındaki ayrımın basit bir yolu eğer hesaplayabiliyorsan, kontrol edebiliyorsan ve programlayabiliyorsan o halde yönetebiliyorsundur. Hesaba katamıyorsan liderlik yapmak zorundasındır. Yöneticiler açısından yönetmek ve yönetim prosedürlerini uygulamak işlerinin gereğidir. Liderlik için ise önemli hususlar; girişimcilik, motivasyon ve ilham vermedir (Fairholm, 2004: 578). Yöneticilik, bir kurumun amaç, değer ve hedeflerini saptama ve bunları gerçekleştirme; liderlik ise, bir yön belirleme, çalışanların o yönde ilerlemelerini motive etmektir. Liderlik kavramı geleceğe yöneliktir. Liderler, vizyon oluşturmak ve bu vizyonu kurum içinde benimsetmek sürecinden sorumludur. Yöneticilik ise durağandır, yalnız bugünle ilgilidir, sahip olunan vizyonun hayata geçirilmesini sağlar. Kısaca liderlik, bir vizyon oluşturma ve ilham verme süreciyken yöneticilik, yaşanan güne ilişkin sorunların çözülmesiyle ilgili bir işlevdir (Baltaş, 2013:130).

Alanyazında liderlikle ilgili araştırmaların ve teorileştirme çalışmalarının uzun bir geçmişi vardır ve liderlik teorilerinin birbiri üzerine inşa edildiği yani önceki teorilerin model olarak alındığ1 ve sonraki teorilerin ya önceki modelleri geliştirme ya da yeni bir perspektiften ele aldıklanı ifade edilebilir. İlk dönem teorileri liderlerin evrensel karakteristiklerini ortaya çıkarmaya çalıştığından evrensel liderlik teorileri olarak adlandırlır ve bunlar büyük adam ve büyük kadın teorisi ile özellikler teorisi olarak iki gruba yerleştirilebilir. Büyük adam ve büyük kadın teorisi, kişisel nitelik ve yeteneklerin insanları doğal liderler olarak ortaya çıkaracağına ilişkin bir inançtır, kısaca 'lider olunmaz, lider doğulur' özdeyişini yansıtır. Özellikler teorisi ise; etkili liderlikle bağlantulı boy, fiziksel görünüş, enerji, zeka düzeyi, baskınlık, başarı odaklılık gibi kişilik özelliklerini içermektedir (Riggio, 2014: 342-343).

Liderliği davranışsal özelliklere odaklanarak açıklayan davranışsal teoriler konuya farklı bir bakış açısı getirmektedir. Ohio State Üniversitesince yapılan araşturmalarda liderlerin iki davranış boyutu olduğu öne sürülmektedir. Bunlardan ilki, kişiyi dikkate alma ikincisi ise; girişimcilik 
Çivilidağ, A. (2018). Üniversitede rektör adaylarının liderlik davranıșlarının ve liderlik stillerinin rektörlük seçimleri bağlamında incelenmesi. Journal of Human Sciences, 15(1), 77-97. doi:10.14687/jhs.v15i1.4662

ruhudur. Girişimcilik ruhu yüksek olan lider, işi etkili biçimde planlayıp örgütlemekte, grubu oluşturan üyelerle olumlu ilişkiler kurmakta, haberleşmeyi kolaylaştırmakta dolayısıyla iş yönelimli olarak başarı olasılı̆̆ını arttırmaktadır. Kişiyi dikkate alan liderlerse; üyelerle arkadaşça ilişkiler kurmakta, onlara samimi ve dostça yaklaşmakta, bireylerde güven ve saygı uyandırmaktadır (Eren, 2008: 437-438).

Liderlik teorisi üzerine liderlik faktörlerinin kapsamlı bir şekilde ele alandığı bir araştırma sonucunda, iki faktörlü yapının liderlik olgusunun altında yatan yapıyı yeterli düzeyde açıklamadığı görüşü öne çıkmıştır. Bu nedenle liderliğin en az dört faktörlü bir yapıya sahip olması gerektiği araştırmada savunulmuştur. Bu yapılar ve gerektirdiği davranışlar ise ayrıntılı olarak açılanmıştır; Yönlendirici liderlik (directive leadership): talimatlar ve komutlar verme, hedefler verme, koşula bağlı cezalandırma; İşlemsel liderlik (transactional leadership): koşullu maddi ödüller verme, koşullu kişisel ödüller verme; Dönüşümcü liderlik (transformational leadership): Bir vizyon anlayışı sağlama, statükoya meydan okuma, idealist olma, teşvik ve ilham verme olarak sıralanabilir. Son olarak Güçlendirici liderlik (empowering leadership): alternatif düşünmeyi cesaretlendirme, kendini ödüllendirmeyi cesaretlendirme, öz liderliği cesaretlendirme, katıllimc1 hedef oluşturmay1 cesaretlendirme, takım çalışmasını cesaretlendirmedir. Liderlikle ilgili olarak örgütlerde dönüşümü başlatmak ve uygulamak önemli bir faktördür. Dönüşümcü liderler, takipçilerini ileri görüşe ikna etme becerisi göstermede ve önsezinin takipçilerinde gelişmesinde başarılı olmaktadırlar. Böylece bu liderler, takipçilerinde değişim için güçlü bir motivasyonel güç sağlamaktadırlar (Lievens, Van Geit ve Coetsier, 1997: 416).

Burada belirtilen liderlikle ilgili açılamaların ötesinde ayrıca alanyazında farklı liderlik model ve stillerinden de söz edilmektedir. Bass ve Riggio'nun (2006) tam liderlik modeli, üç tür liderliği kapsamaktadır. Bunlardan biri olan dönüşümcü liderlik; takipçilerinin aşırıya kaçan beklentilerini motive etmeyi, yüksek düzeyli takipçilerinin grup ve örgüt içinde bağlanma ve tatminlerini artırmayı gerektirmektedir. İşlemsel liderlik; belirlenen bir amacın başarılması ya da görevin yapılmasında takipçinin performansına dayalı olarak liderin ödül veya ceza vermesiyle ilişkidir. Son olarak, serbest liderlik (laissez-faire leadership), gerekli kararların alınmadığı ve eylemlerin geciktirildiği liderlik stilidir (Kodama, vd., 2016: 885).

Diğer liderlik paradigmalarına bakıldığında. Sözgelimi otantik liderlik (authentic leadership), dört bağlama göre tanımlanmaktadır. Birincisi öz farkındalık; gerçekliği, esas değerlendirmeyi, kişinin güçlü ve zayıf yönlerini kabul etmeyi ve sosyal etkileşimi geliştirmeyi açıklamaktadır. İkincisi bilgi işlemenin dengelenmesi; kişinin kendi bakış açısının ötesinde diğerlerini dinleme ve bilgi almayı ifade etmektedir. Üçüncüsü ilişkisel şeffaflık, kişinin duygularını, diğerleriyle paylaştığı doğruları ya da hatalarını açıkça paylaşma anlamına gelmektedir. Dördüncüsü ahlaki perspektifleri içselleştirmeyi gerektirmektedir. Bir başka grup tarafindan kişinin değerleri bastırlsa da eylemleri açıklamamayı kabul etmektir. Otantik liderlik, psikolojik kapasiteler (güç, yetenek gibi), olumlu örgütsel iklim, öz farkındalık ve takipçilerin kendilerini gerçekleştirme düzeyinde örgütsel sonuçları etkileyen bir liderlik stilidir (Mehmood, vd., 2016: 878).

Hizmetkar liderlik türü, liderin takipçilerinin arzularını, gereksinimlerini merkeze alan özgeci ve bütünsel bir karakteristik olarak tanımlanmaktadır. Örgüt içinde lider konumunda bulunanlar, örgütün finansal amaçlarının ötesinde çalışanların kişisel ve mesleki gelişimlerini ortaya çıkaran hizmetkar liderlik davranışları sergilerler. Sözgelimi bir hizmetkar lider, takipçilerinin arzularını dinleyip anlayarak, takipçilerinin bu amaçlarını başarmasına yardım eder. Diğer liderlik türleriyle karşılaştırıldığında hizmetkar liderlik, özgeci davranışlarıyla takipçilerinden herhangi bir beklenti içinde olmadan daha güvenilir bir rol model olarak hizmet yönelimli hareket eder (Schwarz, vd., 2016: 1026-1027).

Liderliğin grup üzerindeki etkisinden kaynaklanan çeşitli sonuçları vardır, bunlardan biri de takipçi tatminidir. Takipçiler, çağdaş örgütlerin başarısı için kritik öneme sahiptir. Takipçilerin tatmini bir örgüt için hem yaşamsal bir süreç hem de kendi başına bir sonuçtur. Araştırmalar (Follett, 1933; Barnard, 1938; Roethlisberger ve Dickson, 1939), çalışan tatmininin hem kısa hem de uzun dönemde üretkenlik üzerinde tutarlı bir şekilde etkileri bulunduğunu ortaya koymuştur. 
Çivilidağ, A. (2018). Üniversitede rektör adaylarının liderlik davranışlarının ve liderlik stillerinin rektörlük seçimleri bağlamında incelenmesi. Journal of Human Sciences, 15(1), 77-97. doi:10.14687/ihs.v15i1.4662

Yapılan araşturmalar (Kim, 2002; Dionne, 2004; Judge, Piccolo ve Ilies, 2004) sonucunda, liderlik davranışlarıyla tatmin arasındaki bağ ortaya konmuştur (Trottier, Wart ve Wang, 2008: 322).

Akademik örgüt olan üniversitelerdeki liderlik olgusunu, üniversitenin işleyişiyle ilgili ve geleceğiyle ilgili vizyon sağlayan, hiyerarşik yapının en üst konumundaki rektörlerle ilişkilendirmek mümkündür. Türkiye'de ve diğer bazı ülkelerde üniversite yönetiminin hiyerarşik olarak en üst konumundaki karar alıcısına "rektör" unvanı verilmektedir. Rektör'ün sözlük anlamı doğruya yönelten yönetici anlamına gelmektedir. Amerika Birleşik Devletleri ve İngiltere'de rektör yerine "President, Chancellor veya Vice Chancellor" kullanılırken Fransa'da akademi rektörü ifadesi kullanılmaktadır. Dünyanın farklı ülkelerinde üniversite rektörleri ya öğrencileri de içeren konsey tarafindan ya da merkezi yönetim tarafindan atama yoluyla belirlendiği görülmektedir. Örneğin; Almanya'da 1960'lı yıllara kadar üniversite yöneticisine rektör denilirken sonrasinda "Presidant" denmiştir. Almanya'da üniversite yöneticisi seçimi, öğretim üyeleri, asistanlar, öğrenciler ve idari personel temsilcilerinden oluşan küçük bir konsey tarafindan belirlenirken, onay ve atama eyalet eğitim bakanı tarafından yapılmaktadır (Doğramac1, 2007:5-7). Türkiye'de 2547 sayılı yükseköğretim kanununda rektörün görevleri ve seçilme biçimi açılanmıştır. 17 Ağustos 1983'den 3 Ekim 2016'ya kadar, Profesör unvanlı öğretim üyelerinden belirlenen kriterleri karşılayanlar rektörlük seçimi için aday olabiliyorken ve üniversitelerde öğretim üyeleri rektörlük seçimi için oy kullanabiliyorken, 3 Ekim 2016'da çıkarılan 676 Sayılı KHK (md.85) ile üniversitelerde rektörlük seçimleri kaldırılmıştır. Değiştirilen yükseköğretim kanununda rektörler seçim yerine, Cumhurbaşkanı tarafindan atama ile göreve getirilmektedir. "Devlet üniversitelerinde rektör, Yükseköğretim Kurulu tarafindan önerilecek, Profesör olarak en az üç yıl görev yapmış üç aday arasından Cumhurbaşkanınca atanır. Bir aylık sürede önerilenlerden birisinin atanmaması ve Yükseköğretim Kurulu tarafindan, iki hafta içinde yeni adaylar gösterilmemesi halinde Cumhurbaşkanınca doğrudan atama yapılır. Rektörün görev süresi 4 yıldır. Süresi sona erenler aynı yöntemle yeniden atanabilirler. Ancak aynı Devlet üniversitesinde iki dönemden fazla rektörlük yapılamaz. Rektör, üniversite veya yüksek teknoloji enstitüsü tüzel kişiliğini temsil eder. Vakıflarca kurulan üniversitelerde rektör, mütevelli heyetinin Yükseköğretim Kuruluna teklifi ve Yükseköğretim Kurulunun olumlu görüşü üzerine Cumhurbaşkanı tarafından atanır" denmektedir (YÖK, 2547 Sayılı Kanun).

\section{1. Araştırmanın Önemi}

Alanyazında liderlikle ilgili çok sayıda tanım, teori, model ve sınıflamaya yer verilmesi (Barrow, 1977; Judge \& Piccolo, 2004; Avolio \& Gardner, 2005; Pieterse, Knippenberg, Schippers, \& Staam, 2010; Vries, Bakker-Pieper ve Oostenveld; 2010; Derue, Nahrgang, Wellman, \& Humphrey, 2011) aslında hem insanın karmaşık doğasının hem de değişen toplumsal yapının bir nedenidir. İçinde yaşadığımız yüzyıl farklı düşünür ve araştırmacılarca "post endüstriyel toplum, enformasyon toplumu ya da dijital toplum" gibi değişik kavramlarla açılanmaya çalışılmıştır. Gerek insanın doğasının kişilik, alışkanlık, zeka, öğrenme ve yaşam deneyimleri bakımından çeşitlilik göstermesi gerekse zamana göre sosyal ve iş yaşamındaki değişimler liderliğin tek türe dayatılmasını geçerli kılmamaktadır. Geçmişte var olan liderlik yaklaşımları artık yerini yeni liderlik yaklaşımlarına bırakmaktadır (Gül ve Şahin, 2011: 239). Yeni ve farklı yaklaşımlar olsa da yapılan araştırmalarla liderlik olgusunun, liderlik davranışlarının ve liderlik stillerinin anlaşılması, açıklanmaya çalışılması hem yükseköğretim kurumlarında hem de çağdaş iş yaşamında örgütsel davranışla ve işgörenlerin tutumlarılya ilgili önemli öngörü sağlayabilir. Akademik örgütlerde rektörler aldıkları kararlarla, belirledikleri hedef ve politikalarla, kısaca liderlik davranış ve stilleriyle öğretim elemanları ve diğer işgörenler üzerinde iş performansı, iş motivasyonu, işe yönelik tutum, akademik başarı gibi bireysel veya örgüt düzeyindeki iş davranışları üzerinde doğrudan etkili olabilmektedirler. Akademik örgütlerde liderler sahip oldukları özellikleriyle çalışanların başarısı ve mutluluğuna etki eden bir faktör oldukları gibi akademik örgütün huzurlu ve demokratik bir ortama sahip olmasında da etkileri bulunmaktadır. 
Çivilidağ, A. (2018). Üniversitede rektör adaylarının liderlik davranışlarının ve liderlik stillerinin rektörlük seçimleri bağlamında incelenmesi. Journal of Human Sciences, 15(1), 77-97. doi:10.14687/jhs.v15i1.4662

\section{2. Araştırmanın Amac1}

Liderlik, davranış bilimlerinde en kapsamlı araştırılan sosyal etki süreçlerinden biridir. Bunun böyle olmasının nedeni tüm ekonomik, politik ve örgütsel sistemlerin başarısı, liderin etkili ve verimli olmasına bağlıdır. Bir örgütün başarısının anlaşılması kritik bir faktördür, dolayısıyla bu durum örgütlerde liderlik olgusunu çok boyutlu olarak araştırmayı gerektirmektedir (Parris ve Peachey, 2013: 377). Bu araştırma da bu doğrultuda bilim, biloi ve teknoloji üreterek toplumların gelişimine ve değişimine katkı sağlayan akademik örgütlerdeki liderlik davranışlarını (karar verme, amaç ve hedef belirleme, sorun çözme, takipçileriyle ilişki, yeni fikir ve projeler geliştirme gibi) ve liderlik stillerini rektör adaylanı üzerinden anlamak ve açılamak amacıyla yapılmıştır. Bu bakış açısıyla araştırmanın soruları aşağıdaki gibi oluşturulmuştur.

\section{Araştırma Soruları}

1. Rektör adayları, takipçilerini (öğretim üyelerini) etkilemek için ne tür söylemlerde bulunmuştur?

2. Rektör adayları, takipçilerini (öğretim üyelerini) etkilemek için ne tür projeler geliştirmiştir?

3. Rektör adaylarının kendilerini tanıtma söylemi nedir?

4. Rektör adaylarının liderlik stilleri nedir?

\section{Yöntem}

$\mathrm{Bu}$ araştırmada nitel analiz yöntemi uygulanmıştır. Araştırma iki aşamalı olarak gerçekleştirilmiştir. İlk aşama durum çalışmasıdır. Birinci aşamada her bir rektör adayının rektörlük seçimlerinde oy verme hakk1 olan öğretim üyelerine dört aylık süre içinde gönderdiği e-postalar araştırmacı tarafindan bilgisayar üzerinde oluşturulan klasörlerde ayrı ayrı biriktirilmiştir. Bunlardan nitel analiz için uygun olanlar amaçlı örnekleme yöntemlerinden kolayda örnekleme tekniğiyle belirlenmiştir. Nitel araştırmalarda kullanılan dokümanlardan elde edilen verilerin çözümlenmesinde araştırma verilerine içerik analizi uygulanmış, bulgular kısmında betimsel analize de yer verilmiştir. Nitel araştırmalarda doğrudan gözlem ve görüşmenin olanaklı olmadığı durumlarda çalışlan araşturma problemiyle ilişkili yazılı ve görsel malzemeler ve materyaller araşturmaya dahil edilebilir. Bu demektir ki, doküman incelemesi veya analizi tek başına bir araştırma yöntemi olabildiği gibi, diğer nitel yöntemlerin kullanıldığı durumlarda ek bilgi kaynağı olarak da işe yarayabilir. Doküman analizi, araştırılması hedeflenen olgu veya olgular hakkında bilgi içeren yazılı materyallerin analizini kapsar (Yıldırım ve Şimşek, 2013: 217). Araştırmanın ikinci aşaması, nitel analizin yakınsayan paralel deseni doğrultusunda yapılmıştır. Bu aşamada, rektör adaylarının liderlik stillerinin objektif olarak belirlenmesi amacıyla ayııca araştırmacı tarafindan kapalı uçlu anket soruları hazırlanmıştır. Hazırlanan sorularda, alanyazında sıklıkla yer alan on liderlik stilli seçilip, tanımlanmış ve herbir rektör adayını gözlemleme ve dinleme imkanı bulan bağımsız ve gönüllü dört sosyal bilimciye (yanıtlayıcı) rektör adaylarından herbiri için liderlik stilini belirlemeleri amacıyla yanıtlama yapmaları istenmiştir. Yanıtlayıcılardan herbir aday için birden fazla liderlik stiliyle ilgili anket üzerinde işaretleme yapabilecekleri de söylenmiştir. Yanıtlayıcılardan alınan cevaplar araşturmacı tarafindan tablo üzerine işlendiğinde rektör adaylarının yansıttıkları liderlik stillleri ortaya çıkmıştır (Bkz. Tablo. 6). Araşturmaya başlamadan önce tüm rektör adaylarından rektörlük seçimi süresince öğretim üyelerine gönderdikleri e-postaları bu araştırmada kullanabilmek için araştırmacı tarafindan sözlü izin alınmış olup, ayrıca araştırmanın yürütüldüğü üniversitenin etik kurulundan da yazılı izin alınmıştır.

\subsection{Calişma Grubu}

Araştırmanın çalışma grubu yedi rektör adayından oluşmuştur. Çalışma grubunda yer alan rektör adaylarına ilişkin kısmi demografik bilgiler aşağıda Tablo 1'de sunulmuştur. 
Çivilidağ, A. (2018). Üniversitede rektör adaylarının liderlik davranışlarının ve liderlik stillerinin rektörlük seçimleri bağlamında incelenmesi. Journal of Human Sciences, 15(1), 77-97. doi:10.14687/jhs.v15i1.4662

Tablo 1. Rektör adaylarına ait bazı demografik değerler ve herbir rektör adayından takipçilerine gönderilen ve araşturma analizine giren e-posta sayı ve oranları

\begin{tabular}{clllllc}
\hline $\begin{array}{c}\text { Rektör } \\
\text { Adayları }\end{array}$ & Cinsiyet & Yas & Unvan & Uzmanlik Alanı & $\begin{array}{c}\text { Analize Giren } \\
\text { E-Posta } \\
\text { (f) }\end{array}$ & $\begin{array}{c}\text { Analize Giren } \\
\text { E-Posta } \\
\mathbf{\%}\end{array}$ \\
\hline A & Erkek & 52 & Prof.Dr. & Fen Bilimleri & 21 & 7.04 \\
\hline B & Erkek & 54 & Prof.Dr. & Fen Bilimleri & 25 & 8.38 \\
\hline C & Erkek & 43 & Prof.Dr. & Tip Bilimleri & 35 & 11.74 \\
\hline D & Erkek & 55 & Prof.Dr. & Sosyal Bilimler & 33 & 11.07 \\
\hline E & Erkek & 51 & Prof.Dr. & Tip Bilimleri & 48 & 16.10 \\
\hline F & Erkek & 44 & Prof.Dr. & Fen Bilimleri & 45 & 15.10 \\
\hline G & Erkek & 48 & Prof.Dr. & Sosyal Bilimler & 91 & 30.53 \\
\hline Toplam & & & & 298 & 99.96 \\
\hline
\end{tabular}

Tablo 1'de 3 Rektör adayının \%42.85 ağıllkklı olarak Fen Bilimleri alanında çalıştıkları, 2 rektör adayının Tip Bilimlerinde \%28.57 ve yine 2 rektör adayının Sosyal Bilimlerde \%28.57 çalıştıkları görülmektedir. Rektör adaylarının rektörlük seçim süresince takipçilerine gönderdikleri epostalar incelendiğinde; G Kodlu rektör aday1 91 mail \%30.53 ile en fazla takipçilerine e-posta gönderirken, A Kodlu rektör aday1 21 e-posta \%7.04 ile en az takipçilerine e-posta gönderen rektör adayı olduğu görülmektedir.

\subsection{Verilerin Toplanması}

Araştırmanın çalışma grubunda yer alan yedi rektör adayının her birinden rektörlük seçim süreci içerisinde oy verecek öğretim üyelerini etkilemek, söylemlerini duyurabilmek ve projelerini paylaşmak için Nisan-Temmuz 2016 ayları arasında ayrı ayrı öğretim üyelerine gönderilen 298 eposta araştırmacı tarafindan bu araştırmanın verilerini oluşturmak amacıyla bilgisayar üzerinde oluşturulan bir klasörde biriktirilmiştir. Dolayısıyla bu araştırmanın verileri rektör adaylarının rektörlük seçim süresince takipçilerine gönderdikleri e-postalardan oluşmuştur. Ayrıca rektör adaylarının liderlik stilini belirlemek amacıyla rektörlük seçimi süresince farklı alandan dört sosyal bilimcinin rektör adaylarıyla ilgili gözlem ve değerlendirme sonuçları da bu araşturmanın verileri kapsamindadır.

\subsection{Verilerin Analizi}

Araştırma nitel yönteme göre yapıldığı için, rektör adaylarından gelen e-postalar araştırmacı tarafindan içerik analizine tabi tutulmuştur. Araştırma verilerinin analizinde belirli sırada işlem basamakları izlenmiştir. Bunun için önce her rektör adayına A-G arasında araştırmacı tarafindan alfabetik bir kod verilmiş ve rektör adaylarından gelen e-postalar için bilgisayar üzerinde bir klasör oluşturulmuştur. Düzenli bir şekilde rektör adaylarından gelen her e-posta bu klasörde seçim gününe kadar biriktirilmiştir. Rektör adaylarından gelen e-posta içeriklerinin her biri word programına aktarılmış ve numaralanmıştır. Word programına aktarılan e-postalar içerdikleri mesajlar doğrultusunda araştırmacı tarafindan önce kodlanmıs, sonrasında kodlanan veriler ait oldukları temalar altında toplanmıştır. Araştırmada üç tema belirlenmiştir. Bunlar: Takipçileri etkileme amaçlı söylemler, proje temelli söylemler ve kendilerini tanıtma söylemleri. Kodlama ve temalandırmanın geçerliliği ve güvenilirliği için nitel araştırma deneyimi olan iki araştırmacının uzman görüşlerinden yararlanılmıştır. Bu doğrultuda uzmanlardan gelen öneriler üzerine, bazı kodların (Yeni Üniversite Kütüphanesi yapılması ve Kongrelere maddi destek sağlanması) diğer kodlarla ilişkili olduğu kararına varılarak ilgili tema altında toplanmasına karar verilmiştir. Verilerin kodlanmasında rektör adaylarından gelen e-postalar, dikkatli ve ayrıntılı bir şekilde okunmuştur. Bu aşamada gözden geçirilen her sözcük ya da cümle titizlikle incelenmiş, verilerin sunduğu kavramlar keşfedilmeye çalışılmıstır. Nitel araştırmanın dış geçerliliğini artırmak için ise rektör adaylarının e-postalarından doğrudan alıntı yapılmıştır. Rektör adaylarının liderlik stillerini belirlemek amacıyla katılımcıların 
Çivilidağ, A. (2018). Üniversitede rektör adaylarının liderlik davranıșlarının ve liderlik stillerinin rektörlük seçimleri bağlamında incelenmesi. Journal of Human Sciences, 15(1), 77-97. doi:10.14687/jhs.v15i1.4662

hem takipçilerine gönderdikleri e-postalar analiz edilmiş hem de farklı alanlardan dört bağımsız ve gönüllü sosyal bilimcinin adaylarla ilgili gözlem ve değerlendirmelerinden yararlanılmıştır.

\section{Bulgular}

$\mathrm{Bu}$ bölümde araştırma verilerinden elde edilen bulgular sunulmuştur. Rektör adaylarından gelen e-postalardan elde edilen bulgular ve dört sosyal bilimciden elde edilen gözlem ve değerlendirme sonuçlarına tablolar eşliğinde yer verilmiştir. Bulgular, veri analizi sonucunda ortaya çıkan üç tema (Rektör adaylarının takipçilerini etkileme söylemleri, Proje temelli söylemler ve Kendilerini tanıtma söylemleri) altında ele alınmıştır. Tablo altlarında ise rektör adaylarının görüşlerine doğrudan alıntı yapılmıştır. Doğrudan alıntı sonrasında görüşlerine yer verilen rektör adaylarının alfabetik kodu (A-G arası), tablo numarası, alt tema numarası ve kod numaraları cümle sonundaki paragraf içinde sunulmuştur.

Aşağıda Tablo 2'de rektör adaylarının rektörlük seçim süreci boyunca takipçilerini etkileme söylemleri temasıyla ilişkili dört alt tema ve kodlar sunulmuştur.

Tablo 2. Rektör adaylarının takipçilerini etkileme söylemleri

\begin{tabular}{|c|c|c|c|c|c|c|c|c|}
\hline $\begin{array}{c}\text { 1.Yönetimle İlişkili Söylemler } \\
\text { Alt Teması }\end{array}$ & $\mathbf{A}$ & B & C & $\mathbf{D}$ & $\mathbf{E}$ & $\mathbf{F}$ & G & f \\
\hline \multicolumn{9}{|l|}{ Kodlar } \\
\hline 1.Birliktelik & $\sqrt{ }$ & $\sqrt{ }$ & & $\sqrt{ }$ & $\sqrt{ }$ & $\sqrt{ }$ & & 5 \\
\hline 2.Liyakate önem & $\sqrt{ }$ & $\sqrt{ }$ & $\sqrt{ }$ & & & $\sqrt{ }$ & $\sqrt{ }$ & 5 \\
\hline 3.Kurumsallaşma & $\sqrt{ }$ & $\sqrt{ }$ & $\sqrt{ }$ & & & $\sqrt{ }$ & $\sqrt{ }$ & 5 \\
\hline 4.Şeffaf yönetim & $\sqrt{ }$ & $\sqrt{ }$ & $\sqrt{ }$ & & & & $\sqrt{ }$ & 4 \\
\hline 5.Dişlamayan anlayış & & & $\sqrt{ }$ & $\sqrt{ }$ & & $\sqrt{ }$ & $\sqrt{ }$ & 4 \\
\hline 6.Demokratik yönetim & $\sqrt{ }$ & & $\sqrt{ }$ & & & & $\sqrt{ }$ & 3 \\
\hline 7.Adaletli yönetim & $\sqrt{ }$ & & $\sqrt{ }$ & & $\sqrt{ }$ & & $\sqrt{ }$ & 4 \\
\hline f & 6 & 4 & 6 & 2 & 2 & 4 & 6 & \\
\hline$\%$ & 85.71 & 57.14 & 85.71 & 28.57 & 28.57 & 57.14 & 85.71 & \\
\hline \multicolumn{9}{|l|}{$\begin{array}{l}\text { 2.Bilimsel } \\
\text { Çalışmalara İlişkin Alt } \\
\text { Söylemler Teması } \\
\end{array}$} \\
\hline Kodlar & & & & & & & & $\mathrm{f}$ \\
\hline $\begin{array}{l}\text { 1.Uluslar arasi } \\
\text { ilişkkilerin geliştirilmesi }\end{array}$ & & & & & & $\sqrt{ }$ & $\sqrt{ }$ & 2 \\
\hline 2. Yurt dış1 deneyimi desteği & & $\sqrt{ }$ & & & $\sqrt{ }$ & & & 2 \\
\hline $\begin{array}{l}\text { 3.Araştırma başvuru } \\
\text { ve değerlendirme kolayllğı }\end{array}$ & & $\sqrt{ }$ & & & & & & 1 \\
\hline 4.Araştırma desteği & & $\sqrt{ }$ & & $\sqrt{ }$ & & & & 2 \\
\hline 5.İstatistik birimi kurulması & & & & & & $\sqrt{ }$ & $\sqrt{ }$ & 2 \\
\hline $\begin{array}{l}\text { 6.Bilimsel faaliyetlere } \\
\text { katulımin desteklenmesi }\end{array}$ & & & & & $\sqrt{ }$ & & $\sqrt{ }$ & 2 \\
\hline $\begin{array}{l}\text { 7.Bilimsel çalışmaların } \\
\text { halkla paylaşılması }\end{array}$ & & $\sqrt{ }$ & & & & & $\sqrt{ }$ & 2 \\
\hline $\begin{array}{l}\text { 8.Bilim insanı teșvik } \\
\text { ödülleri verilmesi }\end{array}$ & & $\sqrt{ }$ & & & & & & 1 \\
\hline$f$ & & 5 & & 1 & 2 & 2 & 4 & \\
\hline$\%$ & & 62.50 & & 12.50 & 25 & 25 & 50 & \\
\hline \multicolumn{9}{|l|}{$\begin{array}{l}\text { 3.Eğitim ve Öğretime İlişkin } \\
\text { Söylemler } \\
\text { Alt Teması }\end{array}$} \\
\hline Kodlar & & & & & & & & $\mathrm{f}$ \\
\hline $\begin{array}{l}\text { 1.Yeni } \\
\text { Üniversite Kütüphanesi }\end{array}$ & & $\sqrt{ }$ & $\sqrt{ }$ & & $\sqrt{ }$ & & $\sqrt{ }$ & $\overline{4}$ \\
\hline $\begin{array}{l}\text { 2.Başar1lı ögrencilere } \\
\text { burs verilmesi }\end{array}$ & & & & & & & $\sqrt{ }$ & 1 \\
\hline 3. Yabanc1 dil eğitimi desteği & & $\sqrt{ }$ & & & & $\sqrt{ }$ & $\sqrt{ }$ & 3 \\
\hline f & & 2 & 1 & & 1 & 1 & 3 & \\
\hline$\%$ & & 66.66 & 33.33 & & 33.33 & 33.33 & 100 & \\
\hline
\end{tabular}


Çivilidağ, A. (2018). Üniversitede rektör adaylarının liderlik davranıșlarının ve liderlik stillerinin rektörlük seçimleri bağlamında incelenmesi. Journal of Human Sciences, 15(1), 77-97. doi:10.14687/jhs.v15i1.4662

\begin{tabular}{|c|c|c|c|c|c|c|c|}
\hline 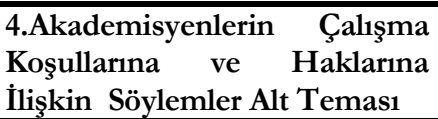 & & & & & & & \\
\hline Kodlar & & & & & & & $\mathrm{f}$ \\
\hline 1.Huzurlu çalışma ortamı & & $\sqrt{ }$ & $\sqrt{ }$ & $\sqrt{ }$ & & $\sqrt{ }$ & 4 \\
\hline $\begin{array}{l}\text { 2.Özlük haklarının } \\
\text { güvenceye alınması }\end{array}$ & $\sqrt{ }$ & $\sqrt{ }$ & $\sqrt{ }$ & $\sqrt{ }$ & & & 4 \\
\hline 3.Yurt dişı ziyaret destekleri & & $\sqrt{ }$ & & & $\sqrt{ }$ & & 2 \\
\hline 4.T1bbi destek verilmesi & & & & & $\sqrt{ }$ & $\sqrt{ }$ & 2 \\
\hline 5.İş yükünün azaltılması & & $\sqrt{ }$ & & & & & 1 \\
\hline 6.Kongrelere maddi destek & & $\sqrt{ }$ & & & & & 1 \\
\hline $\mathrm{f}$ & 1 & 5 & 2 & 2 & 2 & 2 & \\
\hline$\%$ & 16.66 & 83.33 & 33.33 & 33.33 & 33.33 & 33.33 & \\
\hline
\end{tabular}

Tablo 2'de rektör adaylarının takipçilerini etkileme amaçlı gönderdikleri e-postalar incelendiğinde; e-postalardaki mesajların dört alt tema (yönetimle ilişkili söylemler alt temas1, bilimsel çalışmalara ilişkin söylemler alt teması, eğitim ve öğretime ilişkin söylemler alt teması ve akademisyenlerin çalışma koşullarına ve haklanna ilişkin söylemler alt teması) altında kategori oluşturduğu belirlenmiştir. A, C ve $\mathrm{G}$ rektör adaylarının yönetimle ilişkili söylemleri \% $\% 5.71$ ile diğer adaylardan daha fazladır. A rektör adayı, Yönetimle ilişkili alt temada "Dışlamayan anlayışla" ilgili söylemde bulunmazken, C ve G adaylan, "Birliktelik" ile ilgili söylemde bulunmamıştır. Tüm adayların yönetimle ilgili söylemlerde, "demokratik yönetime" en az vurguyu yaptkkları görülmektedir ( $f=3$ ). Bilimsel çalısmalara ilişkin söylemler alt temasında ise $B$ aday1 $\% 62.50$ ve $G$ adayı $\% 50$ oranıyla diğer adaylardan daha fazla bilimsel çalışmalara ilişkin söylemde bulunmuşlardır. Tüm adayların bilimsel çalışmalara ilişkin alt temada "araştırma başvuru ve değerlendirme kolaylĭğı" ve "bilim insanı teşvik ödülleri verilmesi'ne aynı oranda en az vurguyu yaptıkları görülmektedir $(\mathrm{f}=1)$. Eğitim ve öğretime ilişkin söylemler alt temasında $\mathrm{G}$ adayı $\% 100$ oranıyla diğer adaylardan daha fazla eğitim ve öğretime ilişkin söylemlerde bulunmuştur. Bu alt temada tüm adayların "başarılı öğrencilere burs verilmesi"ne en az vurguyu yaptıkları görülmektedir ( $\mathrm{f}=1$ ). Akademisyenlerin çalışma koşullarına ve haklarına ilişkin söylemler alt temasında ise; B adayı $\% 83.33$ oranıyla diğer adaylardan daha fazla akademisyenlerin çalışma koşulları ve haklarına ilişkin söylemde bulunmuştur. Bu alt temada tüm adayların "iş yükünün azaltılması" ve "kongrelere maddi destek"e aynı oranda en az vurguyu yaptıkları belirlenmiştir ( $\mathrm{f}=1$ ). Dört alt temada kategorilendirilen adayların takipçilerine gönderdikleri e-postalarda yer alan ifadeler betimsel yöntemle incelendiğinde ise;

"Gelecek dönemde siz değerli meslektaşlarmla birlikte çalışmak beni son derece mutlu edecektir. Üniversitemiz̨in kurumsal kimliğinin yeniden tesisi ve akademik bedeflerimize ulasmak amaciyla adil, seffaf, liyakate önem veren idari ve akademik yapulanmann her asamasinda bezdirici (mobbing) baskelardan u₹ak, güvenilir bir yönetim ve yöneticilik anlayısı tam anlamiyla hakim olacaktır. Tüm kurullarm demokratik olarak çalsstığ, kararlarmm șeffaf olarak iəlenebildiğgi, tek adam değil, demokratik ortak akhn bakim olduğu ilkeli bir yönetim anlayışndan asla ödïn vermeyeceğiz: Hep birlikte hedefe çok yakımı, önce adaleti tesis edeceğiq.” (A2-1; 1,2,3,4,6,7).

"Bilimsel kaygularn ön planda tutulduğu adalet ve liyakatin önemsendiği, seffaf bir yönetimle işbirliği içinde çalsmaya hazır mısmı?? Kurumsal aidiyet hissinin ve kurum kültürünün güclï olduğu... bir üniversite bedefliyoruz: Demokratik ve katılima yaklașmlar önemseyen dürüst, seffaf ve hesap verebilir bir yönetim. Hiçbir üniversite mensubunun kendini imtiyaz̆ ya da dişlanmus bissetmeyeceği bir akademik ortam... Hiç kimsenin

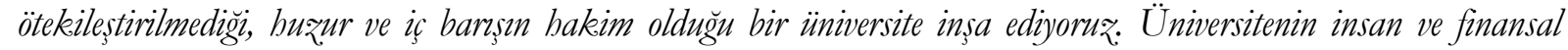
kaynaklarm akademik birimler arasında adaletli dağıtan bir yönetim” (C2-1; 2,3,4,5,6,7).

"Hedefimiz, liyakat, güven, bukuk ve kusatichlle temelinde bir yönetişim pratiği olusturmaktır. Keyfiliğe değgil kurumsallğga oy verin. Rektörlïk görevi süresince katılimcıllk, demokerasi, erişebilirlike, saydamllk ve liyakat 
Çivilidağ, A. (2018). Üniversitede rektör adaylarının liderlik davranıșlarının ve liderlik stillerinin rektörlük seçimleri bağlamında incelenmesi. Journal of Human Sciences, 15(1), 77-97. doi:10.14687/jhs.v15i1.4662

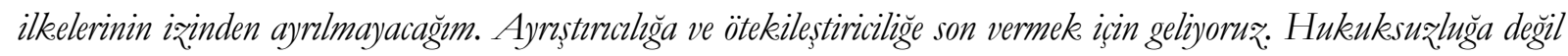
adalete oy verin" (G2-1; 2,3,4,5,6,7).

"Birlikte basarmanm tam zaman. Üniversitemizin birliktelik duygusunu yakalamaya her zamankinden daha

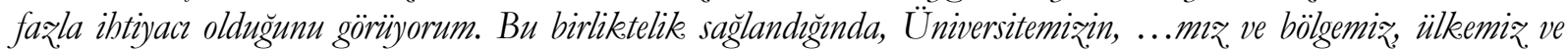
evrensel bilim için nitelikli değerler üretebilecek potansiyele sabip olduğunu biliyorum. Yönetim yaklaşımımıəın öz. taabbüdü Sürdürülebilir basarmm temeli kabul ettiğimiz insan kaynağr politikasi liyakata odaklanacaktır. Üniversitemizde kurumsal yönetişim ilkelerini temel alarak, ücüncü nesil üniversite visyonuna ilerleyeceğiz. Ötekilesstirmeyen, birlikte çallsma kültürünü bakim kilan, kaynaklar verimli kullanan normal bir yönetim için dönüsüm başlad!!'(F2-1; 1,2,3,5).

Rektör adaylarının bilimsel çalışmalara ilişkin alt temasında yer alan söylemleri betimsel yöntemle incelendiğinde;

"BAP kapsammda proje başvuru ve değerlendirme süregleri kolaylastırlacak.. Bilimsel etkinliklere katılim saynlarn ve verilen maddi destek miktarlar arttrulacak.... Üniversitesinde bu ay sloganiyla düzenlenecek konferans dirileriyle ... ve bölge halkı üniversitemizde yapılan çalısmalar, güncel konular ve bölgesel sorunlar bakkemda bilgilendirilecek. Bilim insam ödüllendirme yabanc dil geliştirme, yurt dişı ziyaret destekleri sağlanacak. (B2-2; 3,4,7,8).

"Yurt içindeki ve yurt disındaki önde gelen bilim insanlarmm, akademik zijaretler ve projeler üzerinden üniversitemiz. ile sürdürülebilir iliski kurmasın temin edeceğiq. Büyük veri analiæi ve istatistik birimini kuracağgr. (F2-2; 1,5).

"Uluslararası ilişkilerin etkin kullanım ile yurtdısından gelecek zijyaretçi ögretim üyesi sayısımm artturlması, farkh bilim mecralarmm birikim ve deneyimlerinin ... üniversitesi akademisyenleri ve ögrencileri ile bulusmasmm yolu açlacaktor. İstatistik damısmanllk uygulama ve arastrma merkezinde üniversite ögretim üyelerinin diğer akademik/idari çalşsanlarn ve lisansïstü ögrencilerinin bilimsel araştırma, tę, makale, proje vb. çalısmalarnnda, araștırmanm tasarmmndan, veri analiz̧ ve yorumlanması safbalarna uz̧anan süreçte ibtiyaç duyduklar istatistik danısmanllk bizmeti verilecektir. Akademisyenlerin ulusal ve uluslararası bilimsel toplantılara katılim tesvik edilecek ve BAP desteğine ulaşım kolaylastırlacaktır. ...'yn bir Aģıkhava araştırma sahası olarak görüyoruz: Kent ve bölge ile karşllkkl fayda üretmeyi temel alan bir iliski kurmak en önemli gayelerimizden birini teskil ediyor. Bu gaye doğrultusunda kuracak olduğumuz kent kliniğ̈i...bir koordinasyon merkęi rolü üstlenecektir. Bu klinik. bünyesinde Antalya'da çalıs̆ma hayat, kent yaşamı, sucla mücadele, alt yapr ve eğitim gibi konularda

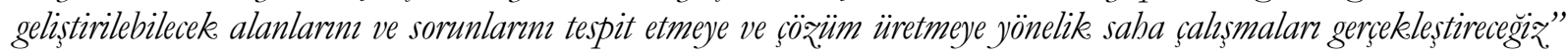
(G2-2; 1,5,6,7).

Rektör adaylarının eğitim ve öğretime ilişkin söylemleri betimsel yöntemle incelendiğinde;

"Ögrrenci motivasyonunun artturlması, iyi örneklerin öne çlkarlması ve ödüllendirici yönetim ilkesinin tatbikine yönelike olarak ĕgitim gördïkleri birimlerde derece yapan ögrencilere teşvik, burs ve ödüllerin sayn ve niteliğinde artrrma gidilecektir. Bölgenin en büyük kütü̈hanesini inșa etmek istiyoruz. Sadece ...'da değil civar kentlerde ögrenim veya akademike faaliyet içerisinde olan arașturmacular için bir entelektüel yașam alan tesskil edecek bir üniversite kütüphanesi hedefliyoru:. Bu bakımdan yetersiz fiziki imkânlar içine sıkışmıs durumda olan merkez. kütüphanemiz için üniversitemiz̧in, kentimizin ve bölgemizin ibtiyaçlarna karşıllk verebilecek ve yedi gün yirmi dört saat hizmet verecek bir kütüh hane binası insa etmek ilk hedefimiz, olacak. Yabancu dil yeterlilik problemi olan personelin, üniversitemiæ. bünyesinde açlacak avantajl kurslara katularak dil ögrenmelerine imkan verileceltir."(G2-3; 1,2,3).

"Öğrenciler ve genç araștırmacular için özel çalısma odalar olan örnek bir kütü̈phaneyi gelin birlikte tasarlayalum ve bizmete sunalm. Akademik personelin basta Ingilizce olmak üzere yabanc dil seviyesini yü̈kseltmek için üniversitemiz, imkanlarm seferber edeceğiz. Üniversitemizde akademik, yazma ve sunum becerilerini gelistirecek 
Çivilidağ, A. (2018). Üniversitede rektör adaylarının liderlik davranıșlarının ve liderlik stillerinin rektörlük seçimleri bağlamında incelenmesi. Journal of Human Sciences, 15(1), 77-97. doi:10.14687/jhs.v15i1.4662

programlar düzenlenecek, aynca ögretim üyelerimiz̨in yaz aylarnda yurt içinde ve dişında yabanc dil eğitim programlarna da katılmalarn sağlanacak.” (B2-3; 1,3).

"Fizilksel alt yapr yatırmlar... Yeni Kütüphane binasi, Kampüs güvenliği alt yapısı, Kampüs doğu girişine kapı, Hasta yakım konaklama oteli gibi yaturmlar hı:̨la bayata geçirilecektir” (C2-3, 1).

"Üniversite kü̈tüphanesi modern ve teknolojik gelismeleri takip ederek, 7/24 akademisyenlerimiz ve ögrencilerimiz. için bizmette olacaktor" (E2-3; 1).

Rektör adaylarının akademisyenlerin çalışma koşullarına ve haklarına ilişkin söylemleri betimsel yöntemle incelendiğinde;

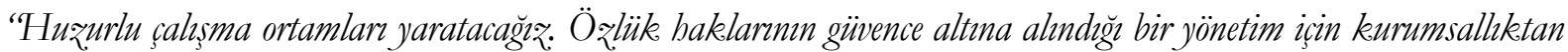
ve seffaflktan asla taviz vermeyeceğiq... Öqlïk haklarm korumak temel görevimizdir. Yabancu dil artık sorun olmayacak, akademike personelin basta Ingilizce olmak üzere yabancu dil seviyesini yü̈kseltmek için üniversitemiz. imkanlarm seferber edeceğiz. Öğretim üyelerimizin yaz aylarnda yurt içinde ve dişında yabancu dil eğitim programlarna da katulmalar sağlanacak. Akademik personelin is yükeü azaltılacak. Birimler tarafindan düzenlenen kongrelere maddi destek verilecek” (B2-4; 1,2,3,4,6,7).

"Gerginliğe değil huحura oy verin. Yabancu dil yeterlilik problemi olan personelin, üniversitemiz, bünyesinde açlacak avantajlı kurslara katularak dil ögrenmelerine imkan verilecektir. Ögretim elemanlar ve birinci dereceden yakinlarm kapsayacak șekilde ayn bir randevu kanah olusturularak akademike kadromuzun üniversitemiz hastanesinden faydalanması kolaylaștırlacaktır"'(G2-4; 1,3,5).

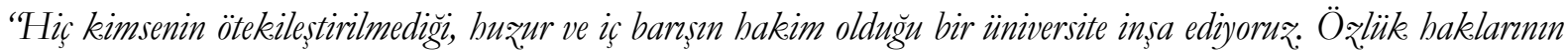
biçbir koşula bağlanmadiğr üniversite..."(C2-4; 1,2).

"Bilim adamlarna üniversiteyi yüceltecek arastrmalar yapmalarna yetecek destekleri săglamaya; ögrrencilere bu乏urla eğitim görecekleri ve nitelikli bir gelecek. kurmalarm sağlayacak bir güzel dünyayn kurmaya geliyoruそ: Barış ve bu乏ur içinde, rengârenke bir düsünsel gücü, bir bilgi mozaiğini kurmaya geliyorn₹: Onurlu sevgili ve bu₹urlu bir

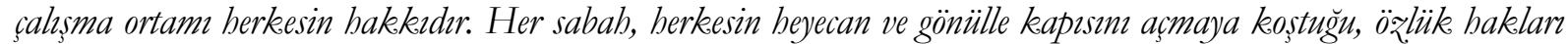
yasal ve akademike alş̧kanhklar kuralina bağh olarak güvence içinde olan çok saygin ve çok sicak bir üniversite bayal ediyorus" (D2-4; 1,2).

"Akademisyenlerimiz, ve ögrencilerimize yurt dișında katulacaklar uluslararast etkinliklerde deneyim imkan. Akademisyenlerimize kendi üniversitelerinde akademisyen dostlar tarafindan sira beklemeden bizmet alma imkan sağlanacaktır"(E2-4; 4,5).

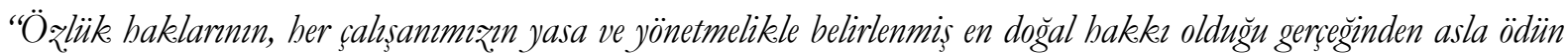
vermeden, her türlü atama, yükseltme ve diğer ö̊lük haklar işlemleri adalet ve liyakat kurallar çerçevesinde en hassas biçimde gerçekleștirilecektir" (A2-4; 2).

"Ingilizce dil bizฺmetleri sunacağrz! Uluslararast ofis bünyesinde, bir yandan akademisyenlerimiz̨in ve ögrencilerimiz̨in yazdğg makalelerin İngilizceye çevrilmesine ve revizyonuna odaklanan, diğer yandan tüm yurt diş

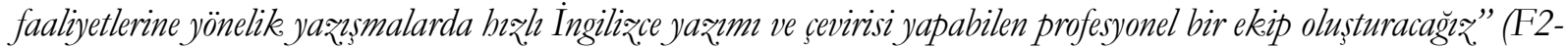
$4 ; 3)$.

Rektör adaylarının takipçilerine gönderdikleri e-postalardaki mesajlarda proje temelli söylemleri aşağıda Tablo 3'de sunulmuştur. 
Çivilidağ, A. (2018). Üniversitede rektör adaylarının liderlik davranışlarının ve liderlik stillerinin rektörlük seçimleri bağlamında incelenmesi. Journal of Human Sciences, 15(1), 77-97. doi:10.14687/jhs.v15i1.4662

Tablo 3. Rektör adaylarının takipçilerine proje temelli söylemleri

\begin{tabular}{|c|c|c|c|c|c|c|c|c|}
\hline Projeler Alt Teması & A & B & C & D & $\mathbf{E}$ & $\mathbf{F}$ & G & $f$ \\
\hline \multicolumn{9}{|l|}{ Kodlar } \\
\hline $\begin{array}{l}\text { 1.Üniversite Sanayi ve } \\
\text { Kent İşbirliği }\end{array}$ & & $\sqrt{ }$ & $\sqrt{ }$ & $\sqrt{ }$ & $\sqrt{ }$ & $\sqrt{ }$ & $\sqrt{ }$ & 6 \\
\hline 2.Ar-Ge Merkezi Kurulması & & $\sqrt{ }$ & $\sqrt{ }$ & & $\sqrt{ }$ & $\sqrt{ }$ & $\sqrt{ }$ & 5 \\
\hline 3.Hukuk Yardım Bürosu & $\sqrt{ }$ & & & & & & $\sqrt{ }$ & 2 \\
\hline 4.Emerita Profesör & $\sqrt{ }$ & & & $\sqrt{ }$ & & & & 2 \\
\hline 5.Aktif Stadyum Projesi & & $\sqrt{ }$ & & & & & & 1 \\
\hline $\begin{array}{l}\text { 6.Yenilenebilir Enerji } \\
\text { Üretim Merkezi }\end{array}$ & & & $\sqrt{ }$ & & & & & 1 \\
\hline 7. 9 T Rulman Modeli & & & & $\sqrt{ }$ & & & & 1 \\
\hline $\begin{array}{l}\text { 8.Özel Eğitim } \\
\text { Kurumlarıyla Anlaşma }\end{array}$ & & & & & $\sqrt{ }$ & & & \\
\hline 9.Proton Terapisi & & & & & & $\sqrt{ }$ & & 1 \\
\hline $\begin{array}{l}\text { 10.Akademi } \\
\text { Meclisleri Kurulmasi }\end{array}$ & & & & & & & $\sqrt{ }$ & 1 \\
\hline $\mathrm{f}$ & 2 & 3 & 3 & 3 & 3 & 3 & 4 & \\
\hline$\%$ & 20 & 30 & 30 & 30 & 30 & 30 & 40 & \\
\hline
\end{tabular}

Tablo 3'de rektör adaylarının takipçilerine proje temelli söylemleri incelendiğinde; A adayı hariç tüm adaylar, "üniversite-sanayi ve kent işbirliği" söyleminde bulunmuştur ( $f=6$ ). $G$ aday1 $\% 40$ oranıyla diğer adaylar arasında takipçilerine en fazla proje söyleminde bulunan aday olmuştur. A ve D adayları hariç tüm adaylar "Ar-Ge merkezi kurulmasını" proje olarak takipçilerine vaat etmiştir. Bazı adayların proje temelli söylemleriyle ilgili olarak takipçilerine gönderdikleri e-postalar betimsel analizle incelenecek olursa;

“...'yn bir acık hava arasterma sahası olarak görïyoruq. Kent ve bölge ile iliskimizi tek tarafl olarak kurgulamyyoruq: Kent ve bölge ile karşllkh fayda üretmeyi temel alan bir iliski kurmak en önemli gayelerimizden birini teşkil ediyor. Bu gaye doğrultusunda kuracak olduğumuz. Kent Kliniği, ögrrencilerimiz̧ ve yetkin araștırmacularmı̨ sahaya sürmede bir koordinasyon merkęi rolü üstlenecektir. Bu klinik bünyesinde ...'da çalşsma hayatı, kent yaşamı, suçla mücadele, altyapı ve eğitim gibi konularda gelistirilebilecek alanlarm ve sorunlarm tespit etmeye ve çözüm üretmeye yönelik saba çalssmalar gerçeklesstireceğiæ. ... Üniversitesi, bir yerleşke üniversitesi değgl bir kent üniversitesi olmalidir. ...Üniversitesi ...sanayisinin işbirliüi ve koordinasyon düzeyi yükeseltilerek hem toplum için ek katma değer yaratılmasina hem de ögretim üyeleri için ek gelir kalemleri olusturulmasina imkan veren bir ortaklık dü̊lemi sağlanacaktır. Bilim ve teknolojiyi sanayicinin ve bölgedeki issletmelerin yararna kullanacak sekilde Ar-Ge imkanlarmm birimler arast ortak kullanmlarma olanak sağlayacak ileri düzeyde bilimsel teknolojik şalısmalarn yapulabileceği işbirlikleri olușturulacaktır. Hukuk fakültesi bünyesinde bukuki problemlerinde ve adli süreclerde akademik personelimize yardımo olacak bir bukuki yardim bürosu olușturulacaktır. Erişebilir ve katılımo yönetim ilkeleri çerçevesinde...periyodik toplantılar yapılacaktır. Akademi meclisleri adı altunda kayda alınacak toplantılar ile üniversite yönetimi, üniversitemiz birimlerinin sorunlarm, projelerini ve hedeflerini yerinde dinleme imkan bulurken üniversitemizin akademisyenlerce doğrudan yönetiminin yolu aģılacaktır" (G3-1; 1,2,3,10).

" Üniversite- Iss Dünyası işbirlĭgi olanaklarm arttracağı. Ar-Ge reform paketi ile getirilen, Ar-Ge içerikli projelerden elde edilen gelirden net \%85 gelir oram avantajim etkili șekilde kullanarak ve bürokratik islemleri

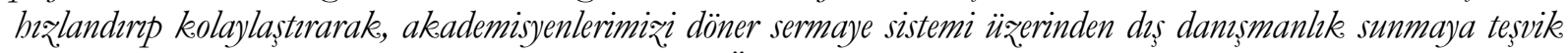
edeceğiq. Proton terapisi ile Sağhlk Turizminde Öncü Olacağrz!... Fiæ̨ibilite çalıs̆mast yapılmıs bu projeyle Üniversitemize yükesek düzeyde kaynak yaratarak Üniversitemiæ̧ dünyanm en büyü̈k bütçeli üniversitelerinden biri baline getireceğiz. (F3-1; 1,2,9). 
Çivilidağ, A. (2018). Üniversitede rektör adaylarının liderlik davranışlarının ve liderlik stillerinin rektörlük seçimleri bağlamında incelenmesi. Journal of Human Sciences, 15(1), 77-97. doi:10.14687/jhs.v15i1.4662

"Üniversite-Sanayi- Kent işbirliğinin hayata geşirildiği, Ulusal ve uluslar arası düreyde Ar-Ge ve Sanayi projeleri üretip mensuplarnmn motive edildiği seçkin üniversite için gönül birliğine davet ediyoru₹. İlimi₹, smorlar içindeki özel eğitim kurumlar ile kurum personeli çocuklarn için özel anlaşmalar yapılacak”"(E3-1; 1,2,8).

"Kentin ve üniversitenin bilgi ve deneyimlerini karşllkl aktardiğg, iki tarafı da yükselten harika bir işbirliği hayal ediyoruz: Emekli ögretim üyelerimiz de bilim ve eğitim faaliyetlerine yine enstitüler çatısı altunda devam edeceklerdir böylece hem enstitülerimiz, gerçek işlevine kavusacak hem de yararlanamadĭğmı iki önemli insan kaynağımı da devreye sokulmus olacaktır. 9T Rulman Modeli Tip, Tarm, Turizm, Teknoloji, Tasarm, Toplum, Ticaret, Tarih, Tabiat (D3-1; 1,4,7).

Rektör adaylanının e-posta ile takipçilerine kendilerini tanıtma söylemlerine ilişkin bulgulara aşağıda Tablo 4'de yer verilmiştir.

Tablo 4. Rektör adaylanının takipçilerine kendilerini tanıtma söylemleri

\begin{tabular}{|c|c|c|c|c|c|c|c|c|}
\hline $\begin{array}{l}\text { Rektör Adaylarının Kendilerini } \\
\text { Tanıtma Söylemleri Alt Teması }\end{array}$ & A & B & C & $\mathbf{D}$ & $\mathbf{E}$ & $\mathbf{F}$ & G & $\mathbf{f}$ \\
\hline \multicolumn{9}{|l|}{ Kodlar } \\
\hline 1.Güçlüyüz & $\sqrt{ }$ & & & & & $\sqrt{ }$ & & 2 \\
\hline 2.Sorumluluk & & & & & & & $\sqrt{ }$ & 1 \\
\hline 3.Deneyim & & $\sqrt{ }$ & & $\sqrt{ }$ & & $\sqrt{ }$ & & 3 \\
\hline 4.Değişim & & & $\sqrt{ }$ & & & $\sqrt{ }$ & & 2 \\
\hline 5.Hak Edilmiş Tecrübe & & & & & $\sqrt{ }$ & & & 1 \\
\hline $\mathrm{f}$ & 1 & 1 & 1 & 1 & 1 & 3 & 1 & \\
\hline$\%$ & 20 & 20 & 20 & 20 & 20 & 60 & 20 & \\
\hline
\end{tabular}

Tablo 4 incelendiğinde; F adayı kendisini tanıtma söyleminde "güçlüyüz, deneyim ve değişim" ifadelerine odaklanırken, B, D ve F adayları kendilerini tanıtma söyleminde "deneyime" odaklanmıştır. Bunların dışında A ve F adayları "güçlüyüz" söylemini ortak ifade olarak kullanırken ( $\mathrm{f}=3$ ), $\mathrm{C}$ ve $\mathrm{F}$ adayları "değişimi”" ortak kendilerini tanıtma söylemi olarak kullanmışlardır. Aşağıda her bir rektör adayının kendilerini tanıtma söylemlerine takipçilerine gönderdikleri e-postalardan alıntı yapılarak yer verilmiştir.

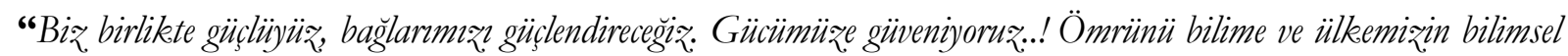
ve teknolojik gelisimine adamıs, uluslararası platformlarda ülkesini basaryla temsil etmis bir akademisyen olarak, ... Üniversitesinin geleceğine sahip çıkma sorumlulü̆unu bissediyorum. Deneyimlerimizi paylașarak üretecek, sadece

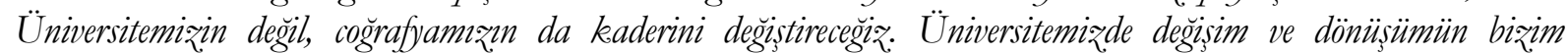
elimiz̨de olduğunun bilincindeyim" (F4-1; 1,3,4).

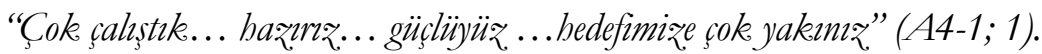

"Akademi, yönetim ve bürokerasi alannda 30 ynh assan deneyimimle Üniversitemiə̧in önündeki sorunlarn assma ve önemli athlimlar gerceklesstirme sürecine önderlik etmeye hąurm" (B4-1; 3).

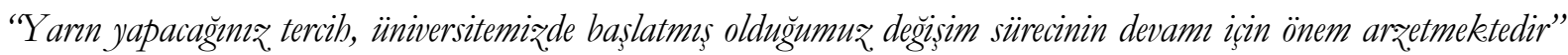
$(C 4-1 ; 4)$.

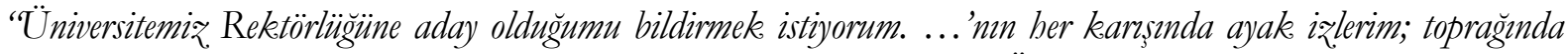
aln terim vardir. 1988'den bu yana ...'nnn ve 1992 sonrasinda da ... Üniversitesi'nin bilinmesine, tanmmasina, ekonomisine, kent ve yurttaşhğmm yükselmesine bižmet ettim. Cok saynda sosyal sorumluluk program yürüttüm. Yüzlerce yaynla ve etkinlikle gereğince bilim de yaptum. Yar bilimsel yazllarmda yüz, binlerce okuyucuya ulastım. Bilim insan ve yazar olarak binlerce sayfay cümlelerim ve düsüncelerimle doldurdum. Hemen her konuda yazdim. 
Çivilidağ, A. (2018). Üniversitede rektör adaylarının liderlik davranıșlarının ve liderlik stillerinin rektörlük seçimleri bağlamında incelenmesi. Journal of Human Sciences, 15(1), 77-97. doi:10.14687/jhs.v15i1.4662

Hemen her konuda yü̈lerce konferans verdim. Büyük projeler ve sanat etkinlikleri gerçeklesstirdim. Bilim-cevre, kültür, sanat, meslek hiæmet, fahri hemserilik gibi konularda ödüllerle toplum ve kurumlardan takdir gördüm”(D4, 3).

"Kazanulmus donanum, Hake edilmis tecrübe, Kararl ve dik duruş" (E4-1; 5).

"Rektörlük görevine adayluğ, yönetme horsı olarak değil, bir üniversite ideasin ve iddiasmn gerceklesstirme sorumluluğu olarak gördük. Rektörlük görevine talip olmanm otorite inșa etmek değil, akeranllk duygusunu ber daim mubafaza etme sorumluluğunun bir gereği olarak bildik."(G4-1; 2).

Rektör adaylarının takipçilerine gönderdikleri e-postalardaki söylemleri doğrultusunda liderlik stillerini belirlemek için rektör adaylarının takipçilerini etkileme amaçlı söylemleri dikkate alınmıştır. Bu nedenle Tablo 2'deki alt temalardan yararlanılmış, ortaya çıkan liderlik stilleri aşağıda Tablo 5'de sunulmuştur.

Tablo 5. Takipçilerine gönderdikleri e-postalar doğrultusunda rektör adaylarında öne çıkan liderlik stilleri

\begin{tabular}{|c|c|c|c|c|c|c|c|c|c|}
\hline Liderlik Stilleri & $\bar{A}$ & B & $\mathrm{C}$ & $\mathbf{D}$ & $E$ & $\mathbf{F}$ & $\mathbf{G}$ & $f$ & $\%$ \\
\hline 1. İş Yönelimli Liderlik & $\sqrt{ }$ & $\sqrt{ }$ & $\sqrt{ }$ & $\sqrt{ }$ & $\sqrt{ }$ & $\sqrt{ }$ & $\sqrt{ }$ & 7 & 100 \\
\hline 2. Demokratik Liderlik & $\sqrt{ }$ & & $\sqrt{ }$ & & & & $\sqrt{ }$ & 3 & 42.85 \\
\hline 3.İlişki Yönelimli Liderlik & & & $\sqrt{ }$ & & & $\sqrt{ }$ & $\sqrt{ }$ & 3 & 42.85 \\
\hline 4.Güçlendirici Liderlik & & $\sqrt{ }$ & $\sqrt{ }$ & $\sqrt{ }$ & & & & 3 & 42.85 \\
\hline 5. Dönüşümcü Liderlik & & & & $\sqrt{ }$ & & $\sqrt{ }$ & & 2 & 28.57 \\
\hline 6.Otoriter Liderlik & & & & & $\sqrt{ }$ & & & 1 & 14.28 \\
\hline 7.Yönlendirici Liderlik & & & & & $\sqrt{ }$ & & & 1 & 14.28 \\
\hline 8.Otantik Liderlik & & & & & & & & 0 & 0 \\
\hline 9.Hizmetkar Liderlik & & & & & & & & 0 & 0 \\
\hline 10.İşlemsel Liderlik & & & & & & & & 0 & 0 \\
\hline
\end{tabular}

Tablo 5'den görüleceği üzere, Tablo 2'de Bilimsel çalışmalara ve projelere ilişkin söylemler alt temasına verilen yanıtların iş yönelimli liderlikle ilişkili olduğu dikkate alındığında, tüm adayların $\% 100$ oranında iş yönelimli liderlik stiline sahip oldukları belirlenmiştir. Tablo 2'de Yönetimle ilişkili söylemler alt temasına verilen yanıtlardan demokratik yönetimin demokratik liderlikle ilişkili olduğu dikkate alındığında, A, C, ve G rektör adaylarının \%42.85 oranında demokratik liderlik stiline sahip oldukları belirlenmiştir. Tablo 2'de Akademisyenlerin çalışma koşullarına ve haklarına ilişkin söylemler alt temasına verilen yanıtların güçlendirici liderlikle ilişkili olduğu dikkate alındığında B, C ve D adaylarının güçlendirici liderlik stiline sahip olduğu belirlenmiştir.

Aşağıda Tablo 6’da gönüllü dört sosyal bilimcinin rektör adaylarının liderlik stilleri hakkındaki gözlem ve değerlendirme sonuçları sunulmuştur.

Tablo 6. Gönüllü dört sosyal bilimcinin gözlem ve değerlendirmelerine göre rektör adaylarının liderlik stilleri

\begin{tabular}{|c|c|c|c|c|c|c|c|c|}
\hline Liderlik Stilleri & $\mathbf{A}$ & $\mathbf{B}$ & $\mathbf{C}$ & $\mathbf{D}$ & $\mathbf{E}$ & $\mathbf{F}$ & $\mathbf{G}$ & $f$ \\
\hline 1.İlişki Yönelimli Liderlik & $\sqrt{ } \sqrt{ }$ & $\sqrt{ }$ & $\sqrt{\sqrt{ }}$ & $\sqrt{ }$ & $\sqrt{ }$ & $\sqrt{ }$ & $\sqrt{\sqrt{ }}$ & 12 \\
\hline 2.İş Yönelimli Liderlik & $\sqrt{ }$ & $\sqrt{ }$ & $\sqrt{\sqrt{ } \sqrt{ }}$ & $\sqrt{ }$ & & $\sqrt{\sqrt{ }}$ & $\sqrt{ }$ & 11 \\
\hline 3.Demokratik Liderlik & & $\sqrt{ }$ & $\sqrt{\sqrt{ }}$ & $\sqrt{ } \sqrt{ }$ & & $\sqrt{\sqrt{ }}$ & $\sqrt{ } \sqrt{ }$ & 10 \\
\hline 4. Dönüşümcü Liderlik & $\sqrt{ }$ & & & $\sqrt{ }$ & $\sqrt{ } \sqrt{ }$ & $\sqrt{ } \sqrt{ }$ & $\sqrt{ }$ & 7 \\
\hline 5.Otoriter Liderlik & $\sqrt{ }$ & $\sqrt{ }$ & & $\sqrt{ }$ & $\sqrt{ } \sqrt{ }$ & & & 5 \\
\hline 6.Yönlendirici Liderlik & $\sqrt{ }$ & $\sqrt{ }$ & & & $\sqrt{ } \sqrt{ }$ & & & 4 \\
\hline 7.Güçlendirici Liderlik & & & $\sqrt{ }$ & & & $\sqrt{\sqrt{ }}$ & & 4 \\
\hline 8.Otantik Liderlik & $\sqrt{ }$ & & $\sqrt{ }$ & & & & $\sqrt{\sqrt{ }}$ & 4 \\
\hline 9.Hizmetkar Liderlik & $\sqrt{ }$ & & $\sqrt{ }$ & & & & & 2 \\
\hline 10.İşlemsel Liderlik & & & $\sqrt{ }$ & & & & & 1 \\
\hline
\end{tabular}


Çivilidağ, A. (2018). Üniversitede rektör adaylarının liderlik davranışlarının ve liderlik stillerinin rektörlük seçimleri bağlamında incelenmesi. Journal of Human Sciences, 15(1), 77-97. doi:10.14687/jhs.v15i1.4662

Tablo 6'da dört sosyal bilimcinin seçim sürecinde rektör adaylarının söylem ve davranışları ile ilgili gözlem ve değerlendirmeleri incelendiğinde; A adayının iki sosyal bilimci tarafından ilişki yönelimli liderlik özelliği taşıdığı ortaya çıkmıştır. C adayıyla ilgili dört sosyal bilimci iş yönelimli liderlik stili taşıdığını belirtirken, üç sosyal bilimci demokratik ve üç sosyal bilimci ilişki yönelimli liderlik stili taşıdığını belirtmiştir. D adayı için iki sosyal bilimci demokratik liderlik stili taşıdığını belirtirken; E adayı için iki sosyal bilimci otoriter liderlik, iki sosyal bilimci yönlendirici liderlik ve iki sosyal bilimci dönüşümcü liderlik stili taşıdığını belirtmiştir. F adayı için üç sosyal bilimci iş yönelimli liderlik ve güçlendirici liderlik stili taşıdığını belirtirken, iki sosyal bilimci demokratik ve aynı sayıda sosyal bilimci dönüşümcü liderlik stili taşıdığını belirtmiştir. $\mathrm{G}$ adayı için ise; üç sosyal bilimci ilişki yönelimli liderlik stili taşıdığını belirtirken, iki sosyal bilimci demokratik ve yine iki sosyal bilimci otantik liderlik stili taşıdı̆̆ını belirtmiştir. B adayı hakkında sosyal bilimciler ortak değerlendirmede bulunmazken; bu adayla ilgili demokratik, otoriter, iş yönelimli, ilişki yönelimli ve yönlendirici liderlik özelliği taşıdığını belirtmişlerdir. Genel olarak tüm rektör adaylanının sosyal bilimciler tarafından değerlendirilmesi sonucunda ise; ağırlıklı olarak ilişki yönelimli liderlik stilinin $(\mathrm{f}=12)$ adaylarda bulunduğu, bunu iş yönelimli liderlik stilinin ( $\mathrm{f}=11)$ ve demokratik liderlik stilinin $(\mathrm{f}=10)$ takip ettiği söylenebilir.

\section{Tartışma Sonuç ve Öneriler}

Bu araştırma nitel bir çalışma olması nedeniyle elde edilen sonuçlar tüm akademik örgütlere genellenemez. Ayrıca araştırma, çalışmanın yapıldığı üniversiteyle, üniversitenin rektörlük seçimleri sırasında rektör adaylarının takipçilerine gönderdikleri e-postalarla ve rektör adaylarının liderlik stillerinin belirlenmesi için gözlemciler tarafindan uygulanan gözlem yöntemiyle ve ayrıca rektör adaylarının erkek cinsiyetli olmalarıyla sınırlıdır.

Araştırmada liderlik davranışları ve liderlik stilleri, üniversite rektör adaylarının takipçilerine gönderdikleri e-postalar üzerinden ve rektör adaylarını gözlemleyen dört sosyal bilimcinin gözlemleri ve değerlendirmeleri üzerinden incelenmiştir. Çalışma bağlamında bulgular genel olarak değerlendirildiğinde, rektör adaylarının ağırlıklı olarak yönetimle ilgili ve akademisyenlerin çalışma koşullarına ve haklarına ilişkin söylemlerde bulundukları belirlenirken, bilimsel çalışmalara ve eğitim ve öğretime ilişkin daha az söylemde bulundukları belirlenmiştir. Bu sonuca göre, üniversitelerin yüksek öğretim ile bilimsel araştırmalar yapma gibi iki temel görevinin rektör adaylarınca ihmal edildiği söylenebilir. Bilgi toplumu insanı, yaratıcıllğga ve yenilikçiliğe önem veren insandır. Üniversitelerin, bu tip insanı yetiştirme sorumluluğu bulunmaktadır. Bilgi toplumuna geçmenin gerekli koşulu kitle eğitimi, sürekli eğitim, elit eğitim gibi kavramlarla birlikte, yükseköğretimin önemini artırmaktır. Diğer ülkelerde olduğu gibi Türkiye'de de üniversitenin gerçekte iç içe geçmiş iki temel görevi olduğu görülmektedir. Yükseköğretim kanununda belirtilen bu görevlerden birincisi, ülkenin ihtiyacı olan alanlarda ve sayıda nitelikli insangücü yetiştirerek, toplumun yerel ve ulusal ölçüde üretim ve yaşam standartlarının yükselmesine katkıda bulunmaktır. İkincisi, hem belirlenen hedefler doğrultusunda hem de toplumsal gereksinimlerden hareketle bilimsel çalısmalar yapmaktır (Korkut, 2001: 177-227).

Rektör adaylarının rektörlük seçimi sürecinde takipçilerini etkilemek için geliştirdikleri projeler, değerlendirildiğinde "üniversite, sanayi-kent işbirliği ile Ar-Ge merkezi kurulması" ağırlıklı olarak öne çıkan projeler olmuştur. Üniversite, sahip olduğu bilimsel bilgi, eğitsel donanım ve teknolojik gelişme potansiyeliyle kentin ekonomik ve sosyal gelişimine önemli katkı sağlamaktadır. Üniversitenin gelişebilmesi, toplumun diğer katmanlarını olumlu olarak etkileyebilmesi için kentle ve üretim sağlayan sanayi kesimiyle de etkileşim içinde olmasını gerektirmektedir. Ar-Ge, yeni ürün ve üretim süreçlerinin ortaya çıkarılmasına yönelik sistemli ve yaratıcı çalışmalardır. Ar-Ge, bilim ve teknolojinin gelişmesini sağlayacak yeni bilgileri elde etmek veya mevcut bilgilerle yeni malzeme, ürün ve araçlar üretmek, yazılım üretimi dahil yeni sistem, süreç ve hizmetler oluşturmak veya mevcut olanları geliştirmek amacı ile yapılan düzenli çalışmalardır (Zerenler, Türker ve Şahin, 2007: 656). Üniversitelerin hem daha fazla bilimsel araştırma yapabilme, teknoloji geliştirme hem de nitelikli öğrenci yetiştirebilmek için ekonomik kaynaklara ihtiyacı bulunmaktadır. Endüstri 
Çivilidağ, A. (2018). Üniversitede rektör adaylarının liderlik davranışlarının ve liderlik stillerinin rektörlük seçimleri bağlamında incelenmesi. Journal of Human Sciences, 15(1), 77-97. doi:10.14687/jhs.v15i1.4662

örgütlerinin de artan rekabet koşullarına ve yeni teknolojik değişimlere uyum sağayabilmek için bilimsel bilginin üretildiği üniversitelere gereksinimi vardır. Bu karşllıklı bağlllık üniversitelerle endüstri örgütlerini işbirliğine zorlamaktadır. Bilgiye dayalı ekonomilerde akademik örgütlerin rolü topluma refah yaratmak ve ekonomik gelişmedir. Önceleri bilimsel bilgi ve teknoloji büyük ölçüde ekonominin dışındaydı ancak halihazırda akademik araştırma, ekonominin yenilik ve gelişme döngüsü içinde daha fazla yer almaktadır. Endüstri, üniversiteye hem bilimsel yeniliğin bir kaynağ1 olarak hem de teknolojik buluşların ve yenilik sürecinin öncüsü olarak bakmaktadır. Sayıları gün geçtikçe artan akademik örgütler, araştırma yapabilmek için ekonomik zorluklarla başetmek durumunda kalmıştır. Bu nedenle üniversiteler temel değerleri olan öğretim ve araştırma faaliyetlerini sürdürmek için endüstri ile Ar-Ge bağlamında işbirliğine gitmek durumunda kalmıştır (Debackere, 2000:323). Üniversiteler bilimsel ilerlemenin öncü üreticileri olurken, endüstri ile birlikte üniversiteler yeni teknolojilerin ve buna bağlı olarak ekonomik büyümenin yaratıcıları olmuştur. Küresel rekabet, bilimsel bilginin yenilik gerektiren süreçlerde daha fazla etkili olması, araştırmalarda devlet desteğinin azalmaya başlaması gibi nedenler özellikle son 25 yılda üniversitesanayi işbirliği uygulamalarında büyük artışlara, son 5-10 yılda da işbirliği modellerinde önemli değişikliklere neden olmuştur. Özellikle küçük ve orta ölçekli sanayi ağırlıklı, geleneksel sektörlere yönelik üretim yapan, Ar-Ge yatırımının düşük olduğu ve geliştirme çalışmalarında dış desteklerden pek yararlanmayan endüstri yapıları için, bölgesel üniversitelerin anahtar rol üstlendiği evrimsel üçlü sarmal modelinin (Devlet-üniversite-sanayi) bilgi tabanlı gelişmede önemli katkılar sağlayabileceği öngörülmektedir. İrlanda, Dublin'de, Trinity Üniversitesinde son on yılda sağlanan gelişmeler bu duruma örnek olarak verilmektedir (Kiper, 2004: 82-89).

Günümüz iş yaşamında çeşitli örgütlerde (üretim, hizmet, teknoloji ve bilgi üreten örgütler vb.) çalşanlar için liderlik önemli unsurlardan biridir, çünkü liderler sahip oldukları karakteristik, davranış ve liderlik özellikleriyle gerek işgörenler, gerekse örgüt iklimi ve örgütsel hedeflerin gerçekleştirilmesiyle ilgili başarı üzerinde önemli etkiye sahip olabilmektedir. Bu etki çalısanların moral, verimlilik, işe ve örgüte bağlllık, iş doyumu ve iş motivasyonu gibi çok sayıdaki faktörle çalışanların hem işle ilgili duygu, düşünce ve davranışları üzerinde hem de örgütle ilgili yaşantıları üzerinde belirleyici olabilir. Liderlerin çalışanlarının iş talepleriyle ilgili olması, çalışanların işlerine daha olumlu bakmalarına ve motivasyonlarının artmasına neden olmakta, bu durum da çalışanların genel olarak iş performanslarını artırmaktadır (Koene, Vogelaar ve Soeters, 2002: 194). Alanyazın incelendiğinde; liderlik stilleri ile çalışanların iş performanslanı, iş doyumlanı, kişilik özellikleri, işten ayrılma niyetleri ve örgütsel bağlllık düzeyleri gibi çok sayıda değişkenle anlamlı ve önemli etkileri olduğunu gösteren sonuçlara rastlanmaktadır (Podsakoff, vd.,1982; Podsakoff, vd., 1984; Korkmaz, 2007; Bakan ve Büyükbeşe, 2010; Batmunkh, 2011; Bogler, 2001; Braun, Peus, Weisweiler ve Frey, 2013; Yeh, vd., 2016; Almandeel, 2017). Bu çalışmalardan bazıları incelendiğinde; Profesör unvanlı akademisyenlerin yönetici (supervisor) olarak yer aldığı, takipçilerin de doktora sonrası ve doktora öğrencileri ve üniversite teknik personeli olarak belirlendiği bir araştırmada dönüşümcü liderliğin hem bireysel hem de takım düzeyinde takipçilerin iş doyumu ve iş performansları üzerinde olumlu ilişkisi olduğu belirlenmiştir (Braun, Peus, Weisweiler ve Frey, 2013: 277). Öğretmenler üzerinde yapılan başka bir araştırmada ise; dönüşümcü liderlik stiline sahip okul müdürlerinin öğretmenlerin iş doyumları ve meslek alg1ları üzerinde hem doğrudan hem de dolaylı olarak etkilerinin bulunduğu belirlenmiştir (Bogler, 2001: 676). Bir başka çalışmada özel eğitim kurumlarında, kamudaki eğitim kurumlarına göre daha fazla demokratik yönetim tarzının uygulandığı belirlenirken, kamu ve özel eğitim kurumlarındaki yöneticilerin daha çok otoriter liderlik tarzı uyguladığı belirlenmiştir (Bakan ve Büyükbeşe, 2010: 82). Araştırma sonuçları alanyazınla uyumlu olarak liderliğin farklı stilleri olduğunu ve her bir liderlik stilinin hem çalışanlar hem de örgütleri etkileyerek farklı değişkenler üzerinde belirleyici olabildiğini göstermektedir. Liderler örgüt içinde farklı tarzlarda davranış sergileyebilmekte ve izleyicilerini bu doğrultuda harekete geçirebilmektedir (Erol ve Köroğlu, 2013: 47). 
Çivilidağ, A. (2018). Üniversitede rektör adaylarının liderlik davranışlarının ve liderlik stillerinin rektörlük seçimleri bağlamında incelenmesi. Journal of Human Sciences, 15(1), 77-97. doi:10.14687/jhs.v15i1.4662

Bu çalışmada akademik örgütü yönetme pozisyonundaki rektör adaylarının liderlik stilleri de belirlenmeye çalısılmıştır. Bunun için hem rektör adaylarının takipçilerine gönderdikleri epostalar incelenmiş hem de rektörlük seçimi sürecinde her bir adayın söylemlerini, projelerini ve kendilerini anlatma olanağı buldukları toplantı ve görüşmelerde bulunan dört bağımsız ve gönüllü sosyal bilim araştırmacısının gözlem ve değerlendirmelerinden yararlanılmıştır. Bu doğrultuda rektör adaylarının liderlik stilleri ile ilgili olarak, adayların takipçilerine gönderdikleri e-postalar incelendiğinde; Tüm rektör adaylarında iş yönelimli liderlik özelliğinin öne çıttı̆̆ (f=7); A,C ve D adaylarının demokratik liderlik stili taşıdığ $(\mathrm{f}=3)$; $\mathrm{C}, \mathrm{F}$ ve $\mathrm{G}$ adaylarının ilişki yönelimli liderlik stili taşıdığ1 ( $\mathrm{f}=3$ ); ve $\mathrm{B}, \mathrm{C}$ ve $\mathrm{F}$ adaylanının güçlendirici liderlik stili taşıdığı belirlenmiştir. Dört sosyal bilimcinin adayların liderlik stilleriyle ilgili gözlem ve değerlendirmeleri bütüncül olarak incelendiğinde ise; adaylarda "ilişki yönelimli liderlik" stilinin öne çıkttğı ( $f=12)$, bunu "iş yönelimli liderlik" stilinin ( $\mathrm{f}=11)$ izlediği ve "demokratik liderlik" stilinin ( $\mathrm{f}=10)$ gözlemcilerce üçüncü sırada tüm adaylarda gözlenen liderlik stili olduğu ortaya çıkmıştır. Hem rektör adaylarının takipçilerine gönderdikleri e-postalar hem de dört sosyal bilimcinin gözlem ve değerlendirme sonuçları bir arada ele alındığında; bu çalısmadaki akademik örgütsel yapıdaki rektör adaylarının liderlik stil ve davranışlarının "ilişki yönelimli, iş yönelimli, demokratik ve güçlendirici liderlik" özellikleri taşıdığ1 söylenebilir.

Gelecekte konu ile ilgili yapılacak araştırmalarda kadın rektörlerin de liderlik davranışları ve liderlik stillerinin erkeklerden ne düzeyde farklılaştı̆̆ ya da benzeştiği incelenebilir. Bu araştırmada bir devlet üniversitesinde rektör adaylarının rektörlük seçim süreci boyunca liderlik davranışları ve liderlik stilleri belirlenmeye çalısılmıştır. Vakıf üniversitelerinde yapılacak çalışmalar ile liderlik davranış ve liderlik stilleri incelenebilir ayrıca bu çalışmalar devlet üniversitelerini içerecek şekilde yapılırsa bu örgütlerdeki hem liderlik davranışları hem de liderlik stilleri karşıllklı incelenerek birbirlerinden farklılıkları ya da benzerlikleri ortaya konulabilir. $\mathrm{Bu}$ araştırmadan farklı olarak gelecekteki araştırmalarda, nicel araştırma yöntemlerinin yanı sıra karma araştırma yöntemleri (mixed type), korelatif ya da deneysel yöntemler ile de akademik örgütlerde liderlik konusu araşturılabilir. Ayrıca liderlik olgusu, liderlik davranışları ve liderlik stilleri üzerinde etkisi olabilecek çeşitli psikolojik özellikler (motivasyon, kişilik, psikolojik iyi oluş, vb.) çeşitli faktörlerle, örgütsel yapı unsurlarıyla, örgütsel değişkenlerle, farklı sosyokültürel yapılarla ilişkili olarak ve farklı modeller içinde ayrıntılı incelenerek, konu daha kapsamlı anlaşılmaya ve açıklanmaya çalışılabilir.

\section{Kaynakça}

Almandeel, S. M. (2017). The mediating role of transformational leadership style on relationship between personality type and turnover intention in Saudi Arabian banking context. International Journal of Organızational Leadership, 6, 109-136.

Avolio, B. J., Walumbwa, F. O., \& Weber, T. J. ( 2009 ). Leadership: Current theories, research, and future directions. Annual Review of Psychology, 60 (1), 421-449. doi: 10.1146/annurev.psych.60.110707.163621

Bakan, İ., \& Büyükbeşe, T. (2010). Liderlik "türleri”" ve "güç kaynakları”na ilişkin mevcut-gelecek durum karşılaştırması: eğitim kurumu yöneticilerinin algılarına dayalı bir alan araştırması. KMÜ Sosyal ve Ekonomik Araștirmalar Dergisi 12 (19), 73-84.

Baltaş, A. (2013). Ekip çalı̧ması ve liderlik. Remzi Kitabevi, İstanbul.

Barrow, Jeffrey. C. (1977). The variables of leadership: A review and conceptual framework. Academy of Management Review, 2(2), 231-251.

Batmunkh, M. (2011). Liderlike tarælar ile örg̈̈tsel bağhllk ve örgütsel sessizllik arasundaki iliski ve bir arastorma. Yayımlanmamış Yüksek Lisans Tezi, Marmara Üniversitesi Sosyal Bilimler Enstitüsü, İstanbul.

Bogler, R. (2001). The influence of leadership style on teacher job satisfaction. Educational Administration Quarterly, 37(5), 662-683.

Braun, S., Peus, C., Weisweiler, S., \& Frey, D. (2013). Transformational leadership, job satisfaction, and team performance: A multilevel mediation model of trust. The Leadership Quarterly 24, 270-283. 
Çivilidağ, A. (2018). Üniversitede rektör adaylarının liderlik davranışlarının ve liderlik stillerinin rektörlük seçimleri bağlamında incelenmesi. Journal of Human Sciences, 15(1), 77-97. doi:10.14687/jhs.v15i1.4662

Debackere, K. (2000). Managing academic R\&D as a business at KU Leuven: context, structure and process. R\&D Management, 30(4), 323-328. doi: 10.1111/1467-9310.00186

Derue, D. S., Nahrgang, J. D., Wellman, N. \& Humphrey, S. E. ( 2011 ). Trait and behavioral theories of leadership: An integration and meta-analytic test of their relative validity. Personnel Psychology, 64(1),7-52. doi: 10.1111/j.1744-6570.2010.01201.x

de Vries, R. E., Bakker-Pieper, A., \& Oostenveld, W. (2010). Leadership = Communication? The relations of leaders' communication styles with leadership styles, knowledge sharing and leadership outcomes, Journal of Business and Psychology, (25), 367-380. doi: 10.1007/S10869-009-9140-2

Doğramac1, İ. (2007). Türkiye'de ve dünyada yükseköğretim yönetimi, http://www.bilkent.edu.tr/hocabey/turkiyede_ve_dunyada_yuksek_ogretim_yonetimi.pdf (04.05.2017).

Eren, E. (2008). Örgütsel davranıs ve yönetim psikolojisi. Beta Basım Yayım, İstanbul.

Erol, G., \& Köroğlu, A. (2013). Liderlik tarzları ve örgütsel sessizlik ilişkisi: otel işletmelerinde bir araştırma. Seyahat ve Otel İsletmeciliği Dergisi/ Journal of Travel and Hospitality Management, 10 (3), 45-64.

Fairholm, M.R. (2004). Different perspectives on the practice of leadership. Public Administration Review, 64,(5), 577-590.

Gül, H., \& Şahin, K. (2011). Bilgi toplumunda yeni bir liderlik yaklaşımı olarak transformasyonel liderlik ve kamu çalışanlarının transformasyonel liderlik algısı. Selçuk Üniversitesi Sosyal Bilimler Enstitïsü Dergisi, 237-249.

Judge, T. A. \& Piccolo, R. F. ( 2004 ). Transformational and transactional leadership: A meta-analytic test of their relative validity. Journal of Applied Psychology, 89 (5), 755-768. doi:10.1037/00219010.89.5.755

Kiper, M. (2004). Teknoloji transfer mekanizmalari ve bu kapsamda üniversite-sanayi işbirliği. Teknoloji,59122.

http://wwwi.globalpiyasa.com/slib/s39862/b80c9bc13b8d15d9f119980511a41d50.pdf\#page=59 (21.04.2017).

Kodama, Y., Fukahori, H., Sato, K., \& Nishida, T. (2016). Is nurse managers' leadership style related to Japanese staff nurses' affective commitment to their hospital?. Journal of Nursing Management, 24, 884 892.

Koene, B. A., Vogelaar, A. L., \& Soeters, J. L. (2002). Leadership effects on organizational climate and financial performance: Local leadership effect in chain organizations. The Leadership Quarterly, 13(3), 193-215.

Korkmaz, M. (2007). Örgütsel sağl1k üzerinde liderlik stillerinin etkisi. Kuram veUygulamada Eğitim Yönetimi ,17(1), 117-139.

Korkut, H. (2001). Sorgulanan yükksek ögretim, 1.Bask1, Nobel Yayın Dağıtım, Ankara.

Lievens, F., Geit, P.V., \& Coetsier, P. (1997). Identification of transformational leadership qualities: An examination of potential biases. European Journal of Work and Organizational Psychology, 6(4), 415-430.

Mehmood, Q., Hamstra, M.R.V., Nawab, S., \& Vriend, T. (2016). Authentic leadership and followers' in-role and extra-role performance: The mediating role of followers' learning goal orientation. Journal of Occupational and Organizational Psychology, 89, 877-883.

Mihai, L., Schiopoiu, A.B., \& Mihai, M. (2017). Comparison of the leadership styles practiced by Romanian and Dutch SME owners. International Journal of Organizational Leadership, 6, 4-16.

Mohamed M. Lamiaa (2016). Assessing the effects of transformational leadership: A study on Egyptian hotel employees. Journal of Hospitality and Tourism Management, 27, 49-59.

Morgan, C.T. (1974). A Brief Introduction To Psychology. McGraw-Hill, NewYork.

Parris, D., Peachey, L., \& Welty, J. (2013). A Systematic literature review of servant leadership theory in organizational contexts. Journal of Business Ethics, 113, (3), 377-393

Pieterse, A.N., Knippenberg, D.V., Schippers, M., \& Staam, D. (2010). Transformational and transactional leadership and innovative behavior: The moderating role of psychological empowerment, Journal of Organizational Behavior, 31, 609-623, doi: 10.1002/job.650

Podsakoff, P.M., Todor, W.D., \& Skov, R. (1982). Effects of leader contingent and noncontingent and noncontingent reward and punishment behaviors on subordinate performance and satisfaction. Academy of Management Journal, 25, 810-821.

Podsakoff, P.M., Todor, W.D., Grower, R.A., \& Huber, V.L. (1984). Situation moderators of leader reward and punishment behaviors: Fact or fiction? Organizational Behavior and Human Performance, 34. 21-63. 
Çivilidağ, A. (2018). Üniversitede rektör adaylarının liderlik davranıșlarının ve liderlik stillerinin rektörlük seçimleri bağlamında incelenmesi. Journal of Human Sciences, 15(1), 77-97. doi:10.14687/jhs.v15i1.4662

Riggio, R. (2014). Endüstri ve örgüt psikolojisine giriş. Çev.Edit.: Belkıs Özkara, Nobel Akademik Yayıncllı, Ankara.

Schwarz, G., Newman, A., Cooper, B., \& Eva, N. (2016). Servant leadership and follower job performance: the mediating effect of public service motivation. Public Administration 94,(4),1025- 1041. doi: $10.1111 /$ padm.12266

Trottier, T., Montgomery, V, W., \& Wang, X. (2008), Examining the nature and significance of leadership in government organizations. Public Administration Review, 319-333.

Yeh, S, C..J., Yuan, K.S., Chen, S.H.S., Lo, Y.Y., Chouh, H.C., Huang, S., Chiu, H.C., \& Wan, T.T.H. (2016). The moderating effect of leadership on the relationship between personality and performance. Journal of Nursing Management 24, 869-883.

Yıldıım, A.\& Şimşek, H. (2013). Sosyal bilimlerde nitel araștrma yöntemleri. Seçkin Yayıncılık, Ankara.

Yüksek Öğretim Kurumu (1981). “2547 Sayll Kanun”.

http://mevzuat.basbakanlik.gov.tr/Metin.Aspx?MevzuatKod=1.5.2547\&MevzuatIliski=0\&sourceX $\underline{\mathrm{mlSearch}}=$ (28.04.2017).

Zerenler, M., Türker, N., \& Şahin, E. (2007). Küresel teknoloji, araştırma-geliştirme (ar-ge) ve yenilik ilişkisi. Selçuk. Üniversitesi Sosyal Bilimler Enstitüsü Dergisi, 1(17), 653-667.

\section{Extended English Summary}

\section{Introduction}

Regardless of economic and social conditions, leadership exists in all societies as people interact with each other. Leadership is not just a qualification of humans, it can be found in many animal species with its most basic forms. Particularly, hierarchy of leadership could be identified through experiments and observation of an animal in its natural environment. Although leadership was an ancient concept, scientists constantly tried to explain this complicated term. Especially in 1960 s, leadership was thought as a combination of duties and behaviors used specifically to direct people. Pioneering description of leadership was outlined as an effect of personality, focusing on group behaviors and a group process. In other attempts to describe leadership, different terms were used such as planning, consolidation, convince, role differentiation, achievement goal effect, power differencies, encourage etc. (Trottier, Wart \& Wang, 2008: 320). While there were many other classifications and descriptions related with leadership. For instance, it was specified 221 leadership descriptions provided in the works published between 1920 and 1990 among which making someone to do something was the most common one. Leadership is a process of influencing someone to achieve a common goal (Mohamed, 2016: 50). Leadership was a process of influencing individuals or groups attitudinally for specific goals and effective leadership was defined in terms of its success (Barrow, 1977: 232). While Kotter (1991) defined leadership as a counseling process used to lead a group in a certain direction, effective leadership was further defined as an act of producing long-term goals for that specific group. Etzioni (1965) defined leadership as a unique power based on personal qualifications which aimed for the area of interests with absolute commitment. In this context, leadership contains persuading people, collecting new ideas, and making precise decisions (Mihai, Schiopoiu \& Mihai, 2017:5).

There is a long history of research and theorization in literature about leadership and it can be stated that leadership theories overlap. Previous theories had been taken as a model while analyzing phenomena in new perspectives. Earliest theories were named as world-wide leadership theories due to their characteristics employing world-wide leaders which could be classified in two groups: great man and great woman theory and feature theories. Great man and great woman theory was a theory that personal qualifications and skills could reveal people as a natural leaders. Put it briefly, it represents the dictum "Leaders are born not made." These theories include personal qualifications such as physical appearance, power, intelligence, prepotency, and success-orientation (Riggio, 2014: 342-343).

Behavioural theories explain leadership by focusing on behavioural qualifications as they bring different perspectives to the subject. Ohio State University produced a study in which two behavioural aspects of leadership were outlined. First, focusing on people and second; focusing on entrepreneurship. Enterprising leaders could plan efficiently, emphasize positive relations with group members, ease communication and this way they could increase the breakthrough success as problem- 
Çivilidağ, A. (2018). Üniversitede rektör adaylarının liderlik davranıșlarının ve liderlik stillerinin rektörlük seçimleri bağlamında incelenmesi. Journal of Human Sciences, 15(1), 77-97. doi:10.14687/jhs.v15i1.4662

oriented. Person-focused leaders have a good turn, friendly and warm attitude towards group members, stir confidence and common sense on individuals.

As a result of a wide research about the Leadership Theory that dealt with leadership factors in the frame of historical analysis, it is stated that two-factor structure cannot explain the underlying structure of leadership. Therefore, it is suggested in the research that leadership should had at least 4factor structure. These structures and their required behaviours could be cited as directive leadership: giving orders and instructions, setting goals, punishment depending on condition; Transactional Leadership: giving tangible rewards depending on condition, giving personal rewards depending on condition; Transformational Leadership: providing a vision, succeeding intuition development of their followers, and lastly, Empowering Leadership: encouraging alternative thinking, encouraging rewarding itself, encouraging self-leadership, encouraging forming participant goal, and encouraging teamwork. Starting and practicing conversion in organizations was an important factor about Leadership and Transformational leaders succeeded in their abilities to convince their followers in improving the foresight of their followers. Thus, these leaders provided a motivational power among their followers for change (Lievens, Van Geit, \& Coester, 1997: 416).

Leadership is one of the most under-researched social effect processes in the behavioral sciences because all of the economic, political and organizational systems' success was connected to leaders' effectiveness and efficiency. It was a critical factor to understand an organization's success. Accordingly, this situation required researching leadership styles in organizations (Parris \& Peachey, 2013: 377). This research was conducted in order to explain and understand the leadership behaviors and leadership styles of rector candidates in academic organizations which contribute to the societies' development by producing science, information and technology. With this point of view, questions of this research were set as given below.

\section{Research Questions}

1- What kind of discourses the rector candidates have used to impress their followers (academics or lecturers)?

2- What kind of projects the rector candidates have provided to impress their followers (academics or lecturers)?

3- What is the discourse of the rector candidates to overview themselves?

4- What are the leadership styles of the rector candidates?

\section{Method}

In this research study, qualitative analysis method was employed. The research has two purposes. One of them is to determine rectors candidates' leadership behaviours and the other is to determine their leadership styles. For the analysis of the data, which were acquired from the documents, content analysis was used and in other piles of the data descriptive analysis was included. Also it was utilized in different field four social scientists' observing and determine about rector candidates' leadership behavior and leadership styles. For this, the researcher was prepared close- ended survey and applied to four social scientist for determining leadership styles of rector candidates. Besides four social scientists had observed all rector candidates during the election rectorship. In the qualitative analysis, direct observation and meeting is impossible, hence, written and visual materials could be added to the study which was related to the research problems set before. This means that document examination or document analysis can be a single-handed research technique which can be useful as an additional source of information when other qualitative techniques were used. Document analysis contains analysis of the written materials which includes data about the targeted fact or facts aimed throughout research (Yıldırım \& Şimşek, 2013: 217). Before starting the study, oral permission was obtained from all the candidates for using the e-mails that they sent to the lecturers during the rector election, also written permission was obtained from the ethics committee of university where the research was being conducted. 
Çivilidağ, A. (2018). Üniversitede rektör adaylarının liderlik davranışlarının ve liderlik stillerinin rektörlük seçimleri bağlamında incelenmesi. Journal of Human Sciences, 15(1), 77-97. doi:10.14687/jhs.v15i1.4662

\section{Procedure}

As it was a qualitative study, content analysis included 298 e-mails coming from rector candidates. In the analysis of the research data, process steps were followed in a certain order. For this, an alphabetic code was given to every rector candidate between $A$ and $G$ and a folder was created on the computer for e-mails coming from rector candidates. Every e-mail received from rector candidates were collected in a folder of computer an orderly manner until the election day. Each e-mail's content was transferred to the word program and was first coded by the investigator in the direction of the messages they contain. Then, the encoded data were collected under the themes to which they belong. Two researchers' -who have qualitative research experience- expert opinions were used for validity and reliability of coding and thematisation. Following including these specialists' opinions in the analysis, it was concluded that some codes (Support for building the new university library and congress) were related with other codes and it was decided to be collected under the related code. While the data were encoded, incoming mails from candidates were read carefully and rigorously. Every word or sentence reviewed at this stage was viewed fastidiously, concepts presented by data were tried to be found out. In order to increase the external reality of qualitative research, direct quotation was extracted from candidates' e-mails. So as to find out rector candidates' manners of leadership, e-mails which were sent to their followers, analysis and observations were made by four volunteers and four independent social scientits.

\section{Results}

When the findings in the context of study are evaluated together, it is seen that while rector candidates make discourses about administration and working conditions of academics and their rights; it has been identified that they do not make discourse much less about scientific studies and education.

When the projects developed by the rector candidates to influence their followers during the election are evaluated, university with the industry-city cooperation and establishment of the research and development became the most prominent project. Regarding the leadership styles of the rector candidates, e-mails sent to the followers of the participants are determined only by candidate $\mathrm{F}$ who has authoritarian and router leadership style. Also all rector candidates have business-oriented leadership style; A, C and G candidates have democratic styles; C,F and G candidates have relation oriented leadership. Four social scientists evaluated and observing about rector candidates' styles of leadership in a holistic perspective and relation-oriented leadership $(\mathrm{f}=12)$, work-oriented leadership ( $\mathrm{f}=11)$ and after that democratic leadership style $(\mathrm{f}=10)$ were observed as common qualities among the rector candidates.

\section{Conclusion}

It is determined that leadership behaviors, which are examined through the e-mails sent to the followers of the rector candidates, are based on the discourses including the terms such as the administration (togetherness, importance of merit, institutionalization, transparent management, understanding to exclude, democratic governance and fair management) and the discourses of candidates points at producing less scientific studies and education-teaching discourses during the rector election process in the university. Most of the rector candidates emphasized the integration of university-industry-city with the establishment of research and development center in their discourses about the project. As a result of examining the rector candidates' e-mails sent to their followers and the observations of the four social scientists from different areas, it could be said that the rector candidates carry the characteristics of relationship oriented, democratic and business-oriented leadership. This study aimed to contribute to the field while trying to understand and explain the leadership behaviors and styles on the context of the rector election. 